\title{
A synthetic ice core approach to estimate ion relocation in an ice field site experiencing periodical melt: a case study on Lomonosovfonna, Svalbard
}

\author{
Carmen P. Vega ${ }^{1}$, Veijo A. Pohjola ${ }^{1}$, Emilie Beaudon ${ }^{2, a}$, Björn Claremar ${ }^{1}$, Ward J. J. van Pelt ${ }^{1}$, Rickard Pettersson ${ }^{1}$, \\ Elisabeth Isaksson $^{3}$, Tõnu Martma ${ }^{4}$, Margit Schwikowski ${ }^{5}$, and Carl E. Bøggild ${ }^{6, b}$ \\ ${ }^{1}$ Department of Earth Sciences, Uppsala University, Villavägen 16, 75236 Uppsala, Sweden \\ ${ }^{2}$ Arctic Centre, University of Lapland, 96101 Rovaniemi, Finland \\ ${ }^{3}$ Norwegian Polar Institute, Fram Centre 9296 Troms $\varnothing$, Norway \\ ${ }^{4}$ Institute of Geology, Tallinn University of Technology, 19086 Tallinn, Estonia \\ ${ }^{5}$ Paul Scherrer Institute, 5232 Villigen PSI, Switzerland \\ ${ }^{6}$ The University Centre in Svalbard, UNIS, Pb. 156 9171, Longyearbyen, Norway \\ a now at: Byrd Polar and Climate Research Center, 082A Scott Hall, 1090 Carmack Road, \\ Columbus, OH 43210-1002, USA \\ b now at: Arctic Technology Centre, Technical University of Denmark, Kemitorvet, \\ Bygning 204, 2800 Kgs. Lyngby, Denmark \\ Correspondence to: Carmen P. Vega (carmen.vega@geo.uu.se)
}

Received: 12 August 2015 - Published in The Cryosphere Discuss.: 29 September 2015

Revised: 9 April 2016 - Accepted: 25 April 2016 - Published: 11 May 2016

\begin{abstract}
Physical and chemical properties of four different ice cores (LF-97, LF-08, LF-09 and LF-11) drilled at Lomonosovfonna, Svalbard, were compared to investigate the effects of meltwater percolation on the chemical and physical stratigraphy of these records. A synthetic ice core approach was employed as reference record to estimate the ionic relocation and meltwater percolation length at this site during the period 2007-2010. Using this method, a partial ion elution sequence obtained for Lomonosovfonna was $\mathrm{NO}_{3}^{-}>\mathrm{SO}_{4}^{2-}, \mathrm{Mg}^{2+}, \mathrm{Cl}^{-}, \mathrm{K}^{+}, \mathrm{Na}^{+}$with nitrate being the most mobile within the snowpack. The relocation length of most of the ions was on the order of $1 \mathrm{~m}$ during this period. In addition, by using both a positive degree day (PDD) and a snow-energy model approaches to estimate the percentage of melt at Lomonosovfonna, we have calculated a melt percentage (MP) of the total annual accumulation within the range between 48 and $70 \%$, for the period between 2007 and 2010, which is above the MP range suggested by the ion relocation evidenced in the LF-syn core (i.e., MP $=30 \%$ ). Using a firn-densification model to constrain the melt range, a MP of $30 \%$ was found over the same period, which is consistent with the results of the synthetic ice core approach, and a $45 \%$
\end{abstract}

of melt for the last 60 years. Considering the ionic relocation lengths and annual melt percentages, we estimate that the atmospheric ionic signal remains preserved in recently drilled Lomonosovfonna ice cores at an annual or bi-annual resolution when weather conditions were similar to those during the 2007-2010 period.

\section{Introduction}

Pollutants produced in low- and mid-latitudes are transported to the polar regions where they are included in the snow by different mechanisms, mainly wet and dry deposition, accumulating in glaciers and ice caps. Major ions, such as $\mathrm{SO}_{4}^{2-}$, $\mathrm{NO}_{3}^{-}, \mathrm{Na}^{+}$, and $\mathrm{Cl}^{-}$, are deposited in the snowpack and can be measured in ice cores, providing valuable information about their sources, chemical transformations in the atmosphere, and transport patterns to the sampling site (Laj et al., 1992; Goto-Azuma and Koerner, 2001; Kekonen et al., 2002; Hastings et al., 2004, 2009). Nitrate $\left(\mathrm{NO}_{3}^{-}\right)$, for example, has been used as a record for past atmospheric 
nitrogen oxides $\left(\mathrm{NO}_{x}=\mathrm{NO}_{2}+\mathrm{NO}\right)$ (Kekonen et al., 2002; Röthlisberger et al., 2002; Hastings et al., 2005, 2009; Vega et al., 2015b). However, this proxy has been difficult to develop since $\mathrm{NO}_{3}^{-}$in snow has several sources and experiences post-depositional processes, such as photolysis, diffusion within the ice, evaporation as $\mathrm{HNO}_{3}$, or relocation by meltwater (Goto-Azuma et al., 1994; Honrath et al., 1999; Rempel et al., 2002; Röthlisberger et al., 2002). The latter has been an enigma to potential ice core sites since relocation and preferential elution of chemical species gives an altitudinal and latitudinal threshold for potential drilling sites. To make use of environmental data from outside the dry snow zones on glaciers in the polar areas, it is important to give better regional coverage of the atmospheric chemistry outside the large polar ice sheets. For a correct interpretation of the chemical ice core data from drilling sites where significant summer melting occurs, it is necessary to estimate the post-depositional effects of meltwater percolation on the chemical content of snow and ice.

It is known that most of the ice core drilling sites at Svalbard experience summer melting, which may dampen the chemical signal of ionic species, making it difficult to understand the transfer function between ion concentrations in the atmosphere and the snow (Goto-Azuma et al., 1994; Isaksson et al., 2001; Moore et al., 2005; Grinsted et al., 2006). Ions do not move uniformly when are removed from the snowpack by meltwater. Instead, they are released following a preferential elution (Goto-Azuma et al., 1994; Eichler et al., 2001; Ginot et al., 2010). The elution of ions is a consequence of sequential grain-scale processes during dry metamorphism (Brimblecombe et al., 1985; Schöndorf and Herrmann, 1987; GotoAzuma et al., 1994) and also influenced by the $\mathrm{pH}$ of meltwater (Goto-Azuma et al., 1994). Moore and Grinsted (2009) calculated the elution factors $(e)$ of several ions present in snow and ice from an ice core drilled at Lomonosovfonna, Svalbard during 1997 (LF-97). According to their results, the most mobile species in the snow were $\mathrm{Ca}^{2+}, \mathrm{Mg}^{2+}, \mathrm{SO}_{4}^{2-}$ and $\mathrm{NO}_{3}^{-}$with $\mathrm{Na}^{+}, \mathrm{Cl}^{-}, \mathrm{NH}_{4}^{+}$and $\mathrm{K}^{+}$being eluted later. The elution sequence changed slightly in ice, where $\mathrm{NO}_{3}^{-}$is the most mobile species and $\mathrm{Mg}^{2+}$ the latest ion to elute. Moore and Grinsted (2009), Ginot et al. (2010) and Eichler et al. (2001) results point to the ionic charge as the control factor in the elution process instead of the acidic character of the ion as reported by Brimblecombe et al. (1985) and GotoAzuma et al. (1994).

The special characteristics of snow and firn properties on high altitude ice fields with heterogeneous stratigraphy as Lomonosovfonna are a consequence of the long winter season with air temperatures below the freezing point, enhanced snow drift due to strong winds, relatively low annual snow accumulation and cold ground surfaces, punctuated by intermittent melt events. The interaction between the meltwater front formed during episodic melt events and the different stratigraphic horizons form preferential flow patterns and create a secondary stratigraphy if refreezing takes place within colder layers (Colbeck, 1991). The secondary stratigraphy produced by refreezing water will have a large influence in meltwater flow and discharge (Bøggild, 2000). During the intermittent melt periods, dislocation of water from more superficial layers percolates into the deeper stratigraphy routed as preferential meltwater flow and the formation of solute enriched ice layers during refreeze of the percolated water will affect the chemistry (i.e., ionic concentrations in this study) recorded in ice cores drilled at the high altitude ice fields of Svalbard.

One estimate to measure if snow melting and percolation have occurred in an ice core stratigraphy is to construct an ion ratio, based on the selection of a pair of ions that originate from the same source but have dissimilar elution coefficients, e.g. $\mathrm{Na}^{+} / \mathrm{Mg}^{2+}$ and $\mathrm{Cl}^{-} / \mathrm{K}^{+}$as reported by lizuka et al. (2002) and Grinsted et al. (2006). Using the logarithms of the different ionic ratios as melt indices, denoted as $W_{\mathrm{NaMg}}$ or $W_{\mathrm{ClK}}$ depending upon the pair of ions selected, a reconstruction of the melting history of a particular ice core site can be reconstructed (Grinsted et al., 2006). Pohjola et al. (2002) found that at Lomonosovfonna, about 25 to $55 \%$ of the annual accumulation over the 20th century may melt and percolate into the underlying snow/firn. The most mobile ions reported by Pohjola et al. (2002) were $\mathrm{NO}_{3}^{-}$and $\mathrm{SO}_{4}^{2-}$, which presented $\sim 50 \%$ higher concentrations in ice compared with firn layers. On the other hand, $\mathrm{NH}_{4}^{+}$presented an even distribution between firn and ice. A percolation mechanism was proposed to have an important role in the redistribution of this species in the ice crystals after deposition. Pohjola et al. (2002) concluded that although some ions may have had a high mobility within the upper part of the LF-97 ice core (0$36 \mathrm{~m}$ deep) during anomalously warm summers, the signal was still identifiable, retained within an annual or biannual resolution.

The aim of this work is to study the temporal change of the snow/firn chemical and physical stratigraphy on the ice field Lomonosovfonna, Svalbard. In this study we will use data from shallow ice cores and snow pits repeatedly studied in 2008, 2009, 2010, and 2011 at Lomonosovfonna to investigate the temporal and vertical change in the stratigraphy and ion composition of the snow/firn column. To manage the sequential change in ion concentrations we will create a synthetic ice core using the top layer $(\sim 1$ year accumulation) of different shallow ice cores and snow pits to have a reference record to assess the relocation of major ions by meltwater and the percolation length at the site during recent years. In addition, the melt percentage of the annual accumulation at Lomonosovfonna is obtained by using a positive degree day and a snow-energy model approach, and used together with the synthetic core to infer the effects of meltwater on the ionic signals present in recent ice cores drilled at Lomonosovfonna. 
Table 1. Drilling site and ice core description for the four different cores used in this study.

\begin{tabular}{llrrrl}
\hline Ice core & Drilling date & Location & Elevation (m a.s.l.) & Length (m) & Reference \\
\hline LF-97 & May 1997 & $78^{\circ} 51^{\prime} \mathrm{N}, 17^{\circ} 25^{\prime} \mathrm{E}$ & 1250 & 121.6 & Isaksson et al. (2001) \\
LF-08 & Mar 2008 & $78^{\circ} 51^{\prime} \mathrm{N}, 17^{\circ} 24^{\prime} \mathrm{E}$ & 1250 & 10.6 & Beaudon (2012) \\
LF-09 & Mar 2009 & $78^{\circ} 49^{\prime} \mathrm{N}, 17^{\circ} 25^{\prime} \mathrm{E}$ & 1200 & 36.0 & Vega et al. (2015b) \\
SP LF-10 & Mar 2010 & $78^{\circ} 49^{\prime} \mathrm{N}, 17^{\circ} 25^{\prime} \mathrm{E}$ & 1200 & 1.5 & This work \\
LF-11 & Apr 2011 & $78^{\circ} 49^{\prime} \mathrm{N}, 17^{\circ} 25^{\prime} \mathrm{E}$ & 1200 & 7.6 & Vega et al. (2015a) \\
\hline
\end{tabular}

\section{Methods}

\subsection{Study sites}

Four ice cores (LF-97, LF-08, LF-09 and LF-11) and a $1.5 \mathrm{~m}$ deep snow pit (SP LF-10) were considered in this study, all retrieved at the Lomonosovfonna ice cap, which is one of the highest glaciated areas in Svalbard with an elevation of $\sim 1250$ m a.s.l. (Isaksson et al., 2001; Beaudon, 2012; Vega et al., 2015b) (Fig. 1). Lomonosovfonna is located northeast of Longyearbyen, which is the largest settlement in Svalbard, and Pyramiden, a smaller settlement where coal mining activities were carried out until 1998. Two of the ice cores (LF97 and LF-08) were drilled at the highest point of the ice cap ca. $100 \mathrm{~m}$ apart from each other, while the LF-09 and LF-11 ice cores were drilled ca. $4.5 \mathrm{~km}$ east-south-east from the site cored in 1997 and 2008 (Fig. 1, Table 1).

\subsection{Sampling and analyses}

The cutting, sampling and chemical analyses of the LF-97 and LF-08 ice cores are reported by Kekonen et al. (2005, and references therein) and Beaudon (2012), respectively. The LF-09 and LF-11 ice core cutting and SP LF-10 sampling were done in clean conditions, wearing clean overalls, face masks and powder free gloves. All materials employed to collect the samples were rinsed with ultra-pure water $(18 \mathrm{M} \Omega)$ and kept in clean plastic bags. Ions were quantified using a Metrohm ProfIC 850 ion chromatographer; samples and standards were melted and handled under laminar flow hood (class 100) to minimize any contamination from the laboratory environment. Samples and standards were placed in the auto-sampler covered with aluminium foil to avoid any dust contamination. Three sample blanks (made of ultra-pure water) were analysed at the beginning and the end of every batch. Sample checks (bulk-snow from Ny-Ålesund or Uppsala) were analysed every 10 samples to ensure the replicability of the measurements within a batch. The analytical error was below $5 \%$ for each ion. Detection limits (D.L.) for each ion were calculated as the average value of six blanks plus 1.68 times the standard deviation $(\sigma)$ of the six measurements (i.e. D.L. $=$ average $_{\text {blank }}+1.68 \times \sigma_{\text {blank }}$ ), being below $0.3 \mu \mathrm{eq} \mathrm{L} \mathrm{L}^{-1}$ for all ions.

Water stable isotopes $\left(\delta^{18} \mathrm{O}-\mathrm{H}_{2} \mathrm{O}\right)$ were analysed at the Institute of Geology at Tallinn University of Technology, Es-

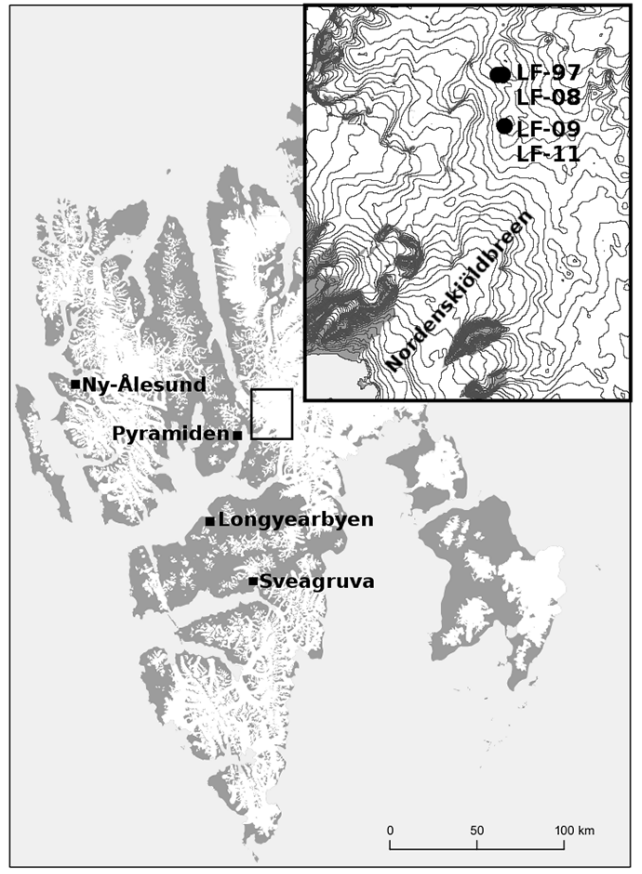

Figure 1. Map of Svalbard showing the main settlements: Longyearbyen, Ny-Ålesund and Pyramiden, and the LF-97, LF-08, LF-09 and LF-11drilling sites at Lomonosovfonna.

tonia. The measurements were done with a Picarro L2120-i water isotope analyser (cavity ring-down spectroscopy technology) with a high precision vaporizer A0211. All isotope measurements were calibrated in a two-point scale against the international standards VSMOW (Vienna Standard Mean Ocean Water) and VSLAP (Vienna Standard Light Antarctic Precipitation). The reproducibility of replicate analysis for $\delta^{18} \mathrm{O}-\mathrm{H}_{2} \mathrm{O}$ measurements was estimated to be $\pm 0.1 \%$.

The ice layer and grain size were inspected in each core section with a visual examination on a lighted bench located in the cold laboratory $\left(-20^{\circ} \mathrm{C}\right)$ at the Norwegian Polar Institute. Bulk density was calculated by weighing and measuring each ice core piece of the LF-97, LF-09 and LF-11 cores. Density in the LF-08 core was estimated using high resolution dielectric profiling (DEP) with a threshold value of $900 \mathrm{~kg} \mathrm{~m}^{-3}$; i.e. values above that were set to NaNs. The stratigraphic melt index was calculated as the percentage of 
Table 2. Synthetic ice core construction using the different Lomonosovfonna shallow cores (LF-08 and LF-09) and SP LF-10 snow pit.

\begin{tabular}{lrr}
\hline Ice core & Depth interval (m w.e.) & Time interval (year) \\
\hline LF-11* & $0.0-0.6$ & $2011.4-2010.4$ \\
SP LF-10 & $0.6-1.4$ & $2010.4-2009.3$ \\
LF-09 & $1.4-1.8$ & $2009.3-2008.3$ \\
LF-08 & $1.8-2.3$ & $2008.3-2007.4$ \\
\hline
\end{tabular}

* The top meter of the LF-11 was not used to construct the synthetic ice core but it is shown here as reference to account for the final depth of the synthetic core.

clear ice present in the ice core (considering the ice core length in $\mathrm{m}$ w.e., $\mathrm{m}$ water equivalent).

\subsection{Synthetic ice core construction}

In order to estimate the effects of meltwater percolation on the chemical record at Lomonosovfonna, a synthetic ice core approach was implemented. This consists of building an unperturbed ice core using only the top meter of the snowpack from different ice cores (top meters of the LF-08 and LF09 cores and the SP LF-10 snow pit), thus constructing a snow-firn record covering the previous year until the date of the sampling/drilling of the previously sampled/drilled snow pit/core during the period 2007-2010 (Table 2). Consequently, summer snow has been included in the synthetic core (Table 2); therefore, no error due to exclusion of this layer is present in the time scale. However, the summer snow in the synthetic core has most probably experienced melting at each interval, i.e. in the summer of 2009, 2008 and 2007 , correspondingly. Since each new segment of the synthetic core starts in the spring of the corresponding year (Table 2), ions that could have been relocated from the summer layer above are not present in the new core segment due to its different origin (Table 2).

\subsection{Calculation of the meltwater}

In order to quantify the meltwater produced at Lomonosovfonna, two independent approaches were used: a simple positive degree day (PDD) model using instrumental temperature data from stations near Lomonosovfonna; and a coupled snow-energy balance model (van Pelt et al., 2012) that delivers snowmelt as output.

\subsubsection{PDD model}

We considered temperature instrumental data from three different sites in Svalbard: Longyearbyen Airport, Sveagruva and Ny-Ålesund (Temperature data, Norwegian Meteorological Institute, 2015). To estimate the number of positive degree days (PDD) at Lomonosovfonna, a lapse rate of $-0.0044^{\circ} \mathrm{C} \mathrm{m}^{-1}$ was used (Pohjola et al., 2002). An annual average number of 37 PDD at Lomonosovfonna was calculated when using the combined temperature records of Longyearbyen Airport, Sveagruva and Ny-Ålesund (i.e. average value of daily temperatures from the three stations), during the period between 1989 and 2010. The meltwater production was calculated as described by Pohjola et al. (2002), using the melt capacity of snow as a function of the PDD at Lomonosovfonna, considering the degree day factor (DDF) as $3.0 \mathrm{~mm}$ water ${ }^{\circ} \mathrm{C}^{-1}$ day $^{-1}$ found at Svalbard after calibration against stake measurements (Nuth et al., 2012). In a recent study by Claremar (2013) that employs Polar Weather Research and Forecast model (Polar WRF) (Skamarock et al., 2008; Wilson et al., 2011) a value for DDF of $25 \mathrm{~mm}^{\circ} \mathrm{C}^{-1}$ day $^{-1}$ of water was found at Lomonosovfonna. However, this DDF value has proven to be too high due to the poor modelling of the net mass balance at Lomonosovfonna when using Polar WRF temperatures and snow accumulation rates for the last decades (Claremar, 2013). Consequently, to calculate the meltwater we employed the DDF value proposed by Nuth et al. (2012), which is more realistic for Lomonosovfonna.

\subsubsection{Coupled snow-energy balance model}

The coupled model was developed to simulate the surface energy balance and subsurface conditions, in order to predict melt, refreezing and runoff at Nordenskiöldbreen, Svalbard and it is described by van Pelt et al. (2012, 2014). The meltwater refreezing output of the grid point located at $1200 \mathrm{~m}$ a.s.l. was used in this study to account for melting at the Lomonosovfonna ice core site. At this elevation runoff does not occur; which implies that all the available water at the surface (from melt and rain) refreezes within the snow/firn pack.

\section{Results and discussion}

\subsection{Dating of the ice cores}

The LF-97 ice core has been dated by different methods (e.g. radioactive horizons, $\delta^{18} \mathrm{O}-\mathrm{H}_{2} \mathrm{O}$ cycles counting, volcanic horizons) having a time scale that covers the past 800 years (Isaksson et al., 2001; Pohjola et al., 2002). An updated time scale for this ice core has been recently published by Divine et al. (2011).

During the 2009 drilling campaign at Lomonosovfonna, two parallel ice cores were drilled: the LF-09 (36 m deep, this study) and a longer core LF-09 $9_{\text {deep }}(149.5 \mathrm{~m}$ deep) (Wendl et al., 2015). Tritium $\left({ }^{3} \mathrm{H}\right)$ measurements done in the LF$09_{\text {deep }}$ ice core estimate the $1963{ }^{3} \mathrm{H}$ horizon (Pinglot et al., 1999) at $23.6 \mathrm{~m}$ w.e., with a resulting accumulation rate of $0.51 \mathrm{~m} \mathrm{yr}^{-1}$ w.e. between the ${ }^{3} \mathrm{H}$ radioactive horizon and the top of the ice core (Wendl et al., 2015). In addition, the high resolution chemical data available for the LF-09 ice core (samples taken each $8 \mathrm{~cm}$ ) allowed the use of a multilinear regression method (MLR) developed by Moore et al. (2012) 

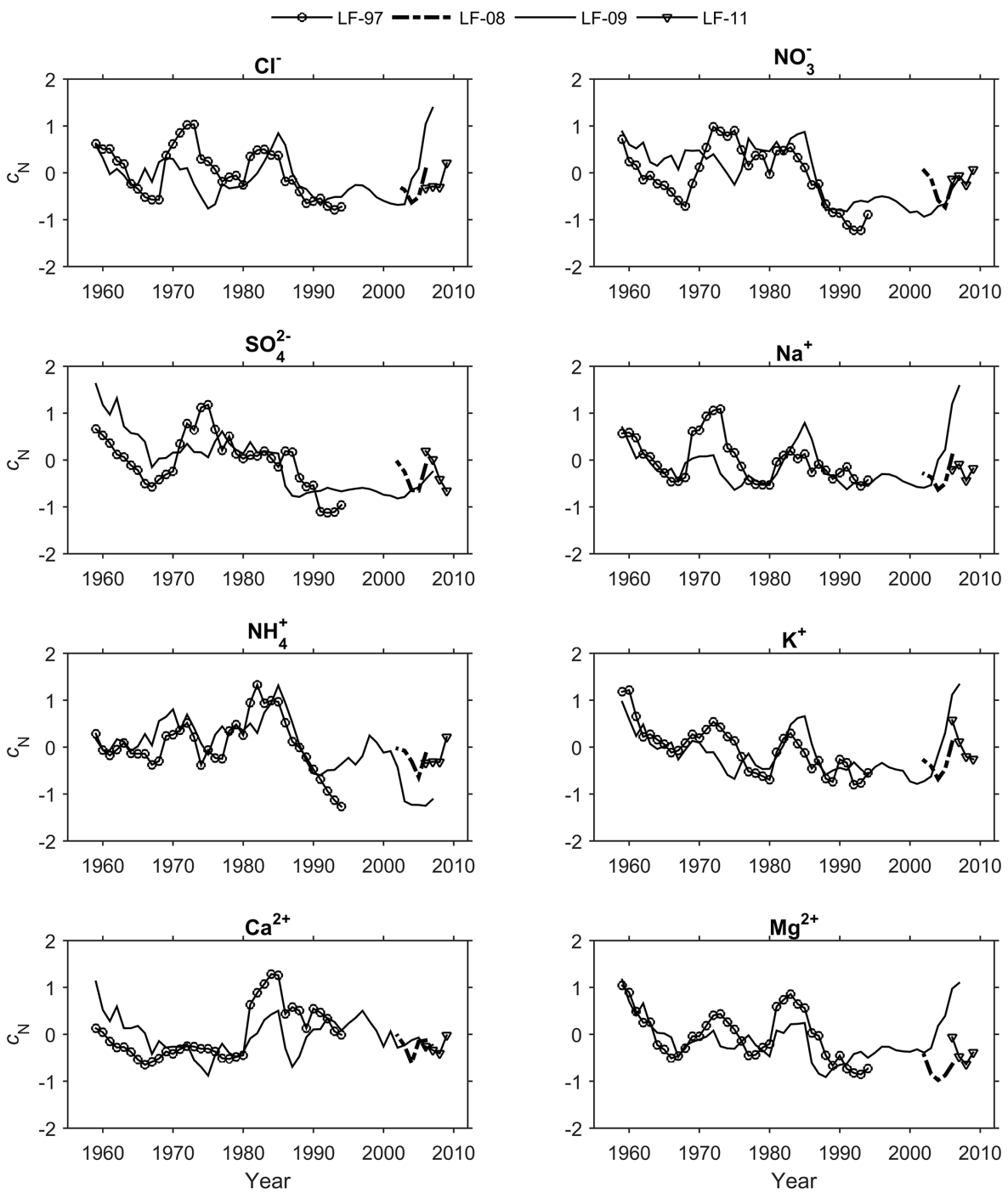

Figure 2. Comparison of normalized ionic concentrations $\left(_{\mathrm{N}}\right)$ in the different LF-ice cores using a 5-year moving average.

to account for volcanic layers in the non-sea salt sulfate concentrations. A detailed description of the usage of the MLR method on the dating of the LF-09 ice core can be found in Vega et al. (2015b). In addition to the MLR method, an automated $\delta^{18} \mathrm{O}-\mathrm{H}_{2} \mathrm{O}$ cycles counting routine was used in the dating. This method counted $\delta^{18} \mathrm{O}-\mathrm{H}_{2} \mathrm{O}$ annual cycles that had an amplitude $\mathrm{A}>0.1 \%$ o $\left(\delta^{18} \mathrm{O}\right.$ uncertainty in the SMOW scale) and a frequency in the sub-annual cycle $\left(\lambda_{\text {seas }}\right)$ larger than $1 / 3$ the accumulation rate (Pohjola et al., 2002). Using both methods, the time scale for the LF-09 core was estimated to span between 1957 and 2009 (Vega et al., 2015b).

The LF-08 and LF-11 ice cores were dated using the automated $\delta^{18} \mathrm{O}-\mathrm{H}_{2} \mathrm{O}$ annual cycles counting routine and by comparing the $\mathrm{Cl}^{-}$record with the respective LF-09 ice core profile.

The LF- 08 core data has only been interpreted between the top and $6.4 \mathrm{~m}$ due to the presence of an anomalous column of clear ice between 6.4 and $10.6 \mathrm{~m}$ deep, which is suspected to be originated by a water-filled crevasse. Clear ice layers of this length have never been observed in any of our ice coring efforts. The summit has a few, but deeply cutting extensional crevasses not visible under the snow cover in the spring. The time scales for the cores were estimated to cover the 20002008 and 2004-2011 periods for the LF-08 and LF-11 (Vega et al., 2015a) ice cores, respectively.

The time scale of the SP LF-10 snow pit was obtained by assuming a constant snow accumulation rate over the depthscale, resulting in time coverage between 2009.4 and 2010.4.

\subsection{Major ions}

All the ionic concentrations were binned to annual averages to obtain equally spaced time series, each of 1 year resolution, which can be compared in between the different ice cores. Having all the chemical species as annual averages, 

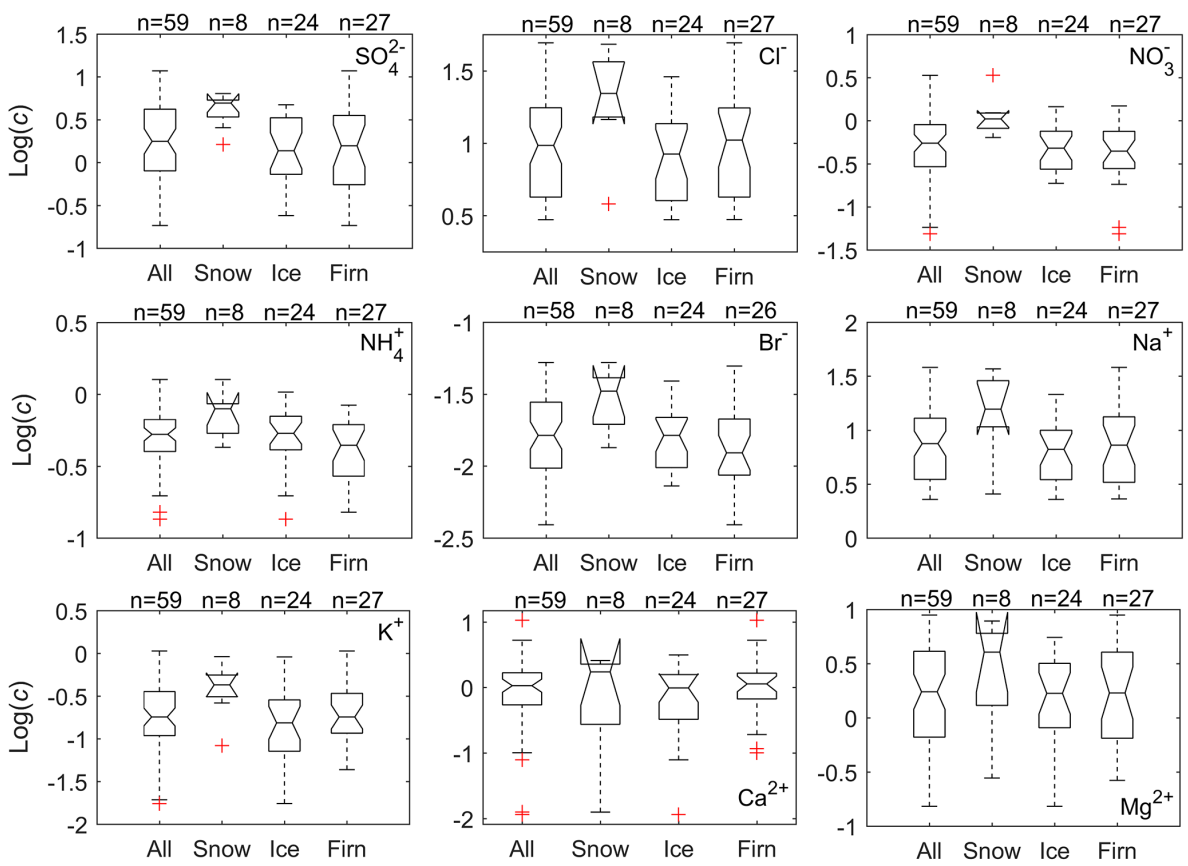

Figure 3. Box plot of $\log$-transformed ionic concentrations $(\log (c))$ found in the different stratigraphic units in the LF-09 ice core between 2004 and 2009. $n$ represents the sample size in each stratigraphic unit, and whiskers are Tukey style.

their concentrations $\left(c_{i}\right)$ were normalized to the mean value for each species in each ice core record, during the total overlapping period (1957-2009), to compare the variations of the ions in the different ice cores (Eq. 1):

$c_{\mathrm{N}}=\frac{c_{i}-c_{\text {mean }}}{\sigma}$,

where $c_{\mathrm{N}}$ is the normalized concentration of a given ion, $c_{\text {mean }}$ is the ion mean in the specific ice core or strata, and $\sigma$ is the standard deviation of the series.

When comparing the annual average concentrations between the different ice cores, some of the peaks show a lag between the different records which likely is associated with the uncertainty of the dating of the three different ice cores. We applied a 5-year moving average smoothing to the annual chemical data (Fig. 2). The dating error of the LF-08 and LF-09, in respect to the LF-97 ice core, was estimated as \pm 2 years. We found that similar temporal variations experienced by the different ions were registered in the different Lomonosovfonna ice cores during the overlapping period studied (Fig. 2).

Table 3 shows the Pearson coefficient $(R)$ and the Wilcoxon rank sum test between the different species in the LF-97 and LF-09 ice cores, smoothed out with 5-year moving averages of the annual data. The Wilcoxon rank sum test was also applied to the ion series in the LF-08 and LF-09 cores to evaluate the hypothesis that ion concentrations in the different LF-cores are samples from continuous distributions with equal medians. The $R$ values between the LF- 08 and LF-09 cores were not calculated since the overlapping pe- riod using 5-year moving average was too short. The $R$ values and the results of the Wilcoxon test in Table 3 suggest that the LF-97 and LF-09 cores, and the LF-08 and LF-09 cores have comparable chemical records for all ions during the period 1956-1996 and 2000-2008, respectively. Consequently, they can be used to interpret the main chemical and climatic patters at Lomonosovfonna at this resolution.

\subsection{Ionic distribution in the snowpack}

In order to investigate to what degree ions are eluted from the snowpack when meltwater percolates, we first compared the $\log$-transformed concentrations $(\log (c))$ of the different species measured in the LF-09 and LF-11 ice cores at different snowpack facies: i.e. snow, ice, and firn. The chemical record of the LF-09 ice core was considered only during the period 2004-2009 when it overlaps with the LF-11 ice core.

Figure 3 shows that the median $\log (c)$ of ions in the LF09 ice core is significantly higher, at a $95 \%$ confidence level, in the snow compared to ice and firn for $\mathrm{SO}_{4}^{2-}, \mathrm{Cl}^{-}, \mathrm{NO}_{3}^{-}$, $\mathrm{Br}^{-}, \mathrm{Na}^{+}$and $\mathrm{K}^{+}$, with higher $\log (c)$ values also for $\mathrm{Ca}^{2+}$ and $\mathrm{Mg}^{2+}$, however, not significant. Moreover, concentrations show similar medians in firn and ice. On the other hand, Fig. 4 shows that median $\log (c)$ in the LF-11 ice core are significantly higher in the snow compared to both ice and firn only for $\mathrm{Br}^{-}$and $\mathrm{Mg}^{2+}$, with $\mathrm{SO}_{4}^{2-}$ median in snow being only significantly higher than in ice. The rest of the ions present even concentrations in all the strata, with the exception of $\mathrm{NH}_{4}^{+}$which shows a higher median concentration in ice compared to firn and snow. 
Table 3. Top table: Pearson coefficients $(R)$ and Wilcoxon rank sum test results ( $p$ values), at a $95 \%$ confidence interval, between the different ions measured in the LF-97 and LF-09 ice cores (normalized concentrations and smoothed out as 5-year running averages). The overlapping period is 1957-1996. $p$ values of the Pearson correlation have been corrected for the reduced degrees of freedom introduced by the 5-year smoothing. Significant values (correlation, $p<0.05$; Wilcoxon rank sum test $p>0.05$ ) are shown in italics. Bottom Table: Wilcoxon rank sum test at a $95 \%$ confidence interval between the different ions measured in the LF-08 and LF-09 ice cores (normalized concentrations and smoothed out as 5-year running averages). The overlapping period is 2000-2008. $N$ represents the sample size.

\begin{tabular}{|c|c|c|c|c|c|c|c|c|}
\hline \multicolumn{9}{|c|}{ LF-97 and LF-09 ice cores } \\
\hline $\begin{array}{l}\text { Ion } \\
R\end{array}$ & $\mathrm{Cl}^{-}$ & $\mathrm{NO}_{3}^{-}$ & $\mathrm{SO}_{4}^{2-}$ & $\mathrm{Na}^{+}$ & $\mathrm{NH}_{4}^{+}$ & $\mathrm{K}^{+}$ & $\mathrm{Ca}^{2+}$ & $\mathrm{Mg}^{2+}$ \\
\hline$(N=36)$ & 0.46 & 0.64 & 0.56 & 0.49 & 0.77 & 0.66 & 0.36 & 0.72 \\
\hline $\begin{array}{l}\text { Wilcoxon rank sum test } \\
(p \text { value, } N=36)\end{array}$ & 0.32 & 0.13 & 0.35 & 0.16 & 0.15 & 0.61 & 1.00 & 0.34 \\
\hline \multicolumn{9}{|c|}{ LF-08 and LF-09 ice cores } \\
\hline $\begin{array}{l}\text { Wilcoxon rank sum test } \\
(p \text { value })(N=5)\end{array}$ & 0.84 & 0.10 & 0.22 & 0.55 & 0.02 & 0.69 & 1.00 & 0.10 \\
\hline
\end{tabular}
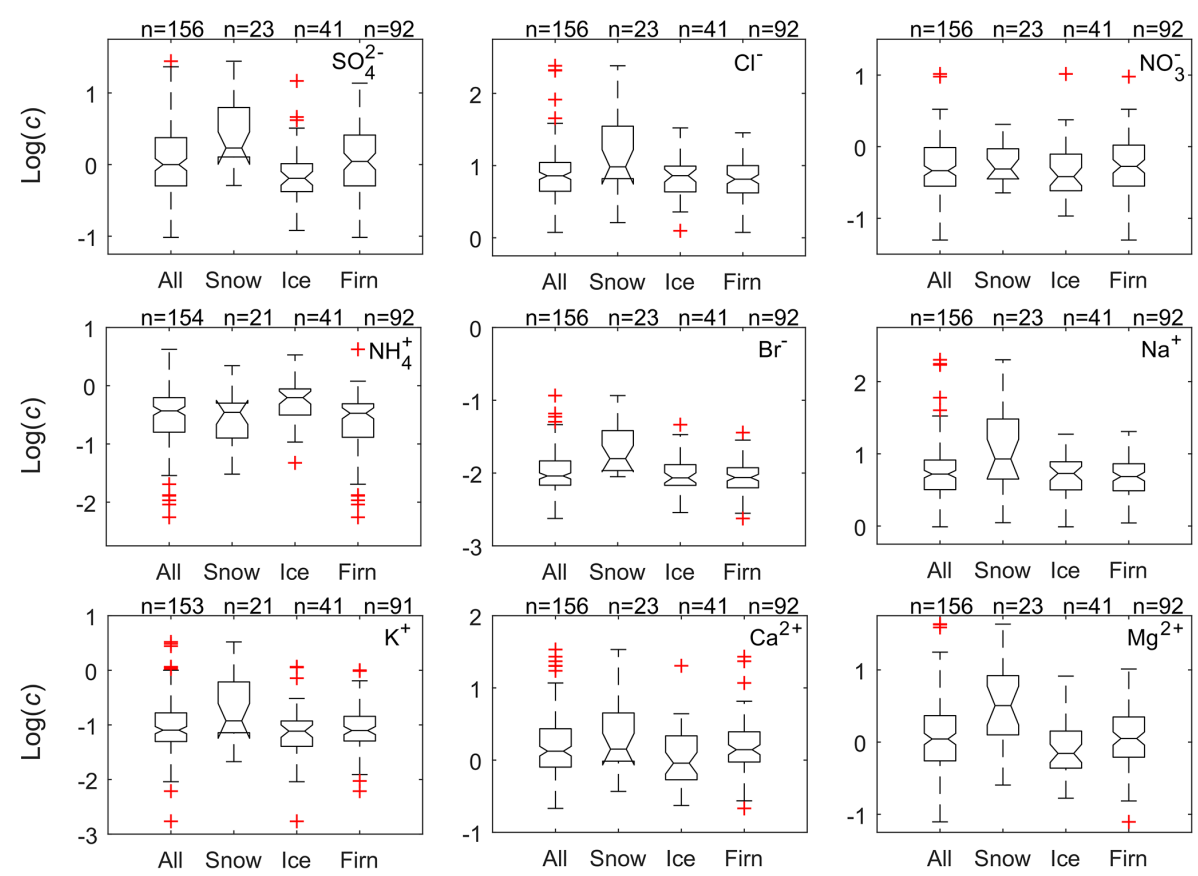

Figure 4. Box plot of ionic concentrations $(\log (c))$ found in the different stratigraphic units in the LF-11 ice core between 2004 and 2011. $n$ represents the sample size in each stratigraphic unit, and whiskers are Tukey style.

Previous work by Pohjola et al. (2002) focused on the effect of periodic melting in the chemical record of an ice core drilled at Lomonosovfonna (LF-97) shows that the average ionic concentrations of the different ionic species were higher in the ice facies than in the firn layers. We observed that this is only significant for $\mathrm{NH}_{4}^{+}$in the LF-11 ice core. Since all ions in the LF-09 and LF-11 ice cores within the period 2004-2011 (10 m deep) are mostly distributed between the snow and firn, we infer that ions in this section of the ice cores have not been heavily relocated by meltwater percolation. Since the amount of meltwater production at the summit of Lomonosovfonna is unknown for the studied years, three different approaches were used in order to estimate and relate it to ionic snowpack redistribution (see Sect. 3.5).

In order to elucidate the evolution of meltwater production over time, the chemical melt index $\left(W_{\mathrm{NaMg}}\right)$ defined as $\log \left(\mathrm{Na}^{+}\right) /\left(\mathrm{Mg}^{2+}\right)$ (using ionic concentrations in $\mu \mathrm{eq} \mathrm{L}^{-1}$ ) (lizuka et al., 2002; Grinsted et al., 2006) was calculated in the different Lomonosovfonna ice cores (Fig. 5). This chemical approach is based on the selection of a pair of ions that have the same source but dissimilar elution coefficients within the snowpack, e.g. $\mathrm{Na}^{+} / \mathrm{Mg}^{2+}$ and $\mathrm{Cl}^{-} / \mathrm{K}^{+}$ 


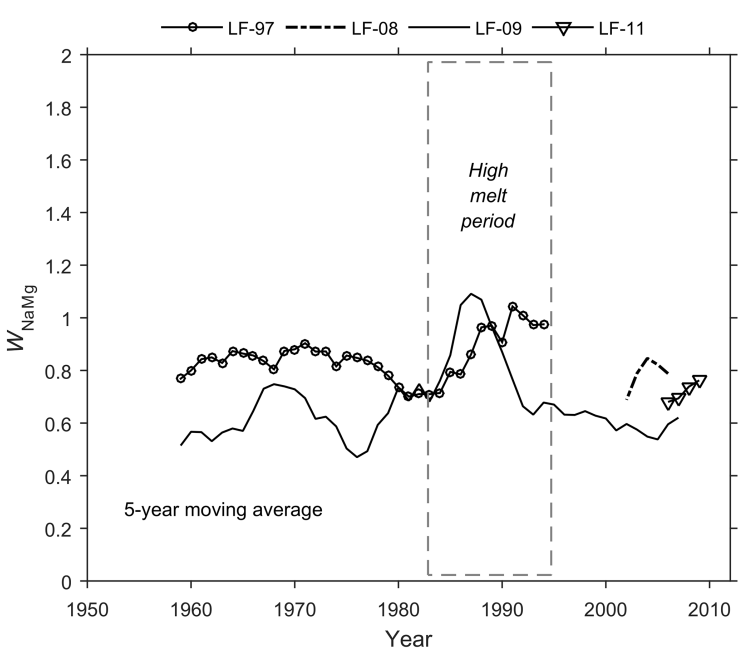

Figure 5. Melt index $W_{\mathrm{NaMg}}$ calculated in the different Lomonosovfonna ice cores. The values correspond to 5-year moving averages. The dashed lines indicates a high melting period during mid-80s to mid-90s.

(Grinsted et al., 2006). Positive $W_{\mathrm{NaMg}}$ values indicate that melting has most probably occurred. This is the case of the four Lomonosovfonna ice cores (Fig. 5) which show positive melt indices during the last 60 years. As observed in Fig. 5, melting at the drilling site is far from being constant; a period of particular high melt is evident during mid-1980s to mid-1990s, which is concomitant with a period of relatively high number of PDDs at Lomonosovfonna. Although the above mentioned method is useful to infer melting regimes at Lomonosovfonna at large time scales (i.e. decadal to centennial), it is not suitable to infer melting at sub-, and multiannual resolutions; therefore, the synthetic ice core approach described in this study presents a suitable option.

\subsection{Synthetic ice core}

Assuming that snowmelt does not occur during winter, and considering that precipitation records of different Svalbard sites show that most of the precipitation is registered during the winter and autumn seasons (Førland et al., 2011), it is expected that the synthetic ice core (LF-syn) captures the unperturbed chemistry of the winter, autumn, summer and early spring seasons between spring 2007 and 2010. Figure 6 shows the annual precipitation cycle at Longyearbyen airport and Ny-Ålesund stations and the precipitation amount and snow accumulation from the two stations and the LF-syn core during the period 2007-2011. The snow accumulation in the LF-syn core was calculated as the length (in mw.e.) between two LF-syn core samples which in average represent 1.2 months of accumulation. Both, the meteorological and the ice core records are coherent with each other, depicting higher accumulation rates during the autumn/winter period than spring/summer. Consequently, it is expected that the LF-syn ice core is representative of the snow accumulation regime at Lomonosovfonna during 2007-2010. The flat accumulation observable during the winter 2010 is due to the assumption of a linear time scale when dating each snow layer of the snow pit dug out in 2010 (SP LF-10). In addition, the average annual mass loading of each ion was calculated for the period 1980-2009 by averaging the annual ion loads calculated in the LF-97 and LF-09 cores. This procedure averaged out the possible effects of percolation and relocation of ions between the strata corresponding to different years. This estimate was then compared with the mass loading of the different ions corresponding to individual years in the LF-syn core (i.e. 2007-2010) which are assumed to represent cumulative autumn-winter-early-spring snow accumulation unaltered by meltwater percolation or ion relocation. It was found that the 5-year LF-syn record represents between 70 and $200 \%$ of the 30-year average ion mass loading with $\mathrm{NH}_{4}^{+}$and $\mathrm{Mg}^{2+}$ located at the bottom and top percentage boundaries, respectively, and $\mathrm{NO}_{3}^{-}$and $\mathrm{SO}_{4}^{2-}$ representing 94 and $111 \%$ of the average, respectively. Keeping in mind that the mass loading for most of the ions show increasing values since 2005 (not shown), thus influencing the percentage of average mass loading in the LF-syn core, we consider that this synthetic core is adequate to investigate ion relocation during the period 2007-2011. The LF-syn core was then compared with the LF-11 core to evaluate the effects of ion elution/deposition between 2007 and 2010 (recorded in the LF-11 ice core) compared to the unperturbed LF-syn ice core (Fig. 7). Since the top part of the LF-11 core (0$0.6 \mathrm{~m}$ w.e.) was not used to construct the LF-syn core (Table 2) and to avoid any bias caused for the snow accumulated after the spring 2010 and 2011, this period was not considered in the normalization of the LF-11 ionic concentrations. Figure 7 shows that the LF-11 record has noticeable large $c_{\mathrm{N}}$ peaks, e.g. around summer 2009, that can be associated with the increase in ionic concentrations by the relocation of ions by the refreezing of percolation water. Figure 8 shows the differences between $c_{\mathrm{N}}$ in both ice cores (LF-11 - LF-syn) calculated after interpolating the records at 0.01-year time steps to homogenize the data. A low-pass filter (half-year moving average) was used to filter out high frequency processes superimposed to the percolation and relocation effect (Fig. 8); consequently, a cutting threshold of half a year was assumed for the relocation of ions. Using the filtered time series shown in Fig. 8, we considered a relocation period when the differences in $c_{\mathrm{N}}$ are positive. Positive differences indicate higher ionic concentrations in the LF-11 ice core with respect to the LF-syn ice core, therefore, ice-firn layers enhanced in ions due to relocation by percolation water. Negative differences indicate ionic elution happening at that layer. Consequently, the study period was divided in four sub-periods denoted with Roman numerals (Fig. 8). It is worth saying, that even though the LF-11 core was used for comparison with the LFsyn core only between April 2007 and April 2010, the effects 

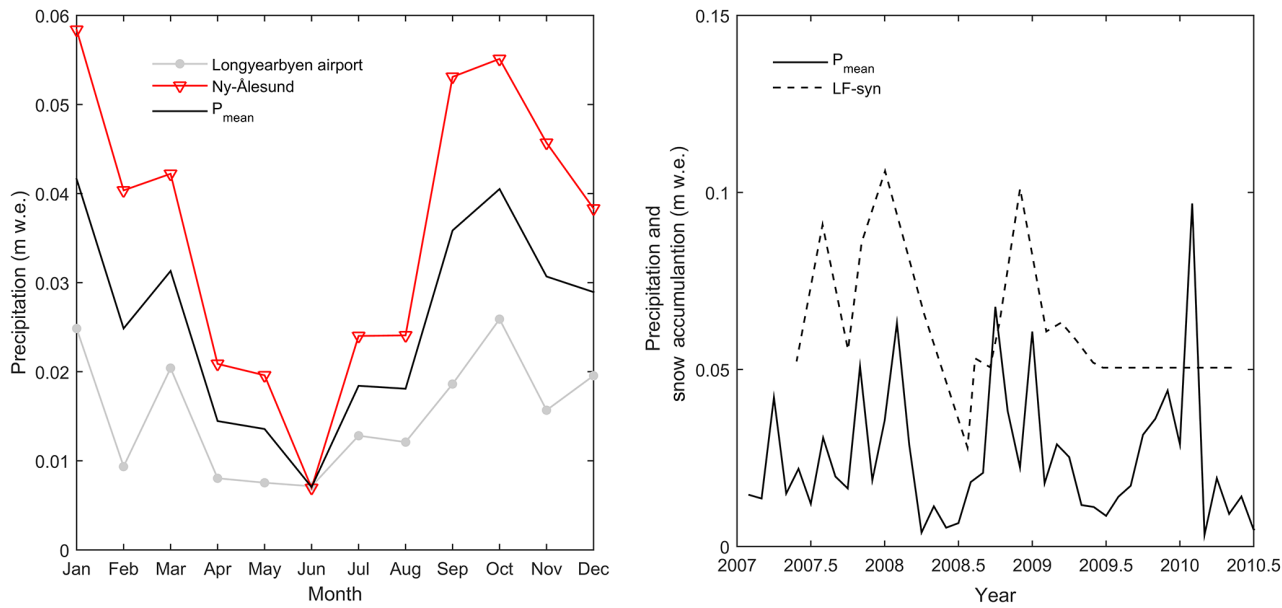

Figure 6. Annual precipitation cycle at Longyearbyen airport and Ny-Ålesund for the period 2007-2011 (left) and monthly precipitation amount at the stations and snow accumulation at Lomonosovfonna given by the LF-syn core (right).

Table 4. Minimum relocation length estimated for each ion measured in the LF-11 ice core.

\begin{tabular}{lrrrrrr}
\hline Ion & $\mathrm{SO}_{4}^{2-}$ & $\mathrm{Mg}^{2+}$ & $\mathrm{Cl}^{-}$ & $\mathrm{K}^{+}$ & $\mathrm{Na}^{+}$ & $\mathrm{NO}_{3}^{-}$ \\
\hline Periods I-II: Relocation length (m) & 1 & 1 & 1 & 1 & 1 & 1.2 \\
Deposition maximum (year) & 2009.76 & 2009.76 & 2009.76 & 2009.76 & 2009.76 & 2009.61 \\
Periods III-IV Elution minimum (year) & 2008.18 & 2008.66 & 2008.76 & 2008.76 & 2008.76 & 2008.18 \\
\hline
\end{tabular}

of melt water produced and percolated during the summer of 2010 are recorded in the LF-11 core. Consequently, Period I encompasses the melting season of the summer-spring months of 2010 (elution period). Period II reflects the deposition period after the spring-summer of 2010. Period III represents elution occurred between summer of 2009 and summer of 2008; and Period IV encompasses a deposition period from spring of 2008 to spring of 2007. From Fig. 8 it can be observed that most of ions (with the exception of $\mathrm{NH}_{4}^{+}$ and $\mathrm{Ca}^{2+}$ ) share similar elution/deposition features in Periods I-IV. We estimate a minimum ionic relocation length as the difference in depth between the minimum and maximum (elution and deposition) $c_{\mathrm{N}}$ peaks observed in Periods I-II (Fig. 8, Table 4). The difference was not calculated in Periods III-IV since the time series are truncated before reaching a maximum value; however the elution minima are noted in Table 4. The relocation length was calculated for all ions, with the exception of $\mathrm{NH}_{4}^{+}$and $\mathrm{Ca}^{2+}$.

Considering the elution/deposition $c_{\mathrm{N}}$ peaks estimated above, a partial ionic elution scheme at Lomonosovfonna for the period 2007-2010 can be inferred, resulting in $\mathrm{NO}_{3}^{-}$being the most mobile ion. This partial elution scheme agrees with previous studies done at Lomonosovfonna (Moore and Grinsted, 2009) which found that $\mathrm{NO}_{3}^{-}$was highly mobile. The partial elution sequence and ion relocation lengths shown in Table 4, suggest that the ions are relocated by meltwater at short lengths, probably trapped in thin and medium- thick ice layers present within the ice column observable in the LF-97, LF-09 and LF-11 cores (Fig. 9), or in refrozen water that soaks the firn column filling the pore space. Nevertheless, the results shown in Fig. 8 and Table 4 are not absolute for the full length of the Lomonosovfonna core but rather the case for years with apparently moderate melting (e.g. MP $<50 \%$ ). In years were summers are warmer and/or longer, ions may percolate further down in the snowpack and get trapped in medium-thick to thick ice layers which start to form at about 3-10 $\mathrm{m}$ deep in the ice column as observable in the LF-97 and LF-09 cores (Fig. 9).

The synthetic core idea was also tested in Greenland snow pit data of the Core Atmospheric Measurements at Summit, Environmental Observatory project available at the NSF Arctic Data Center repository (Summit snow pit data, NSF Arctic Data Center, 2016). We selected two snow pits from Summit: one sampled on 1 July 2012 and the other one sampled in 27 July 2012 (after the melt event of 12 July 2012). We used the density profile and the chemistry record to find an appropriate and realistic match between the ion series. The comparison of the density profiles is shown in Fig. 10. The depth scale of the snow pit sampled in 27 July was adjusted to find a reasonable match with the density profile of the snow pit samples in 1 July. It was necessary to shift the depth profile by $3 \mathrm{~cm}$, which is realistic for the interval of 1 month between the sampling and the amount of water that could have melted in mid-July at the site. According to Nghiem et al. (2012), the 

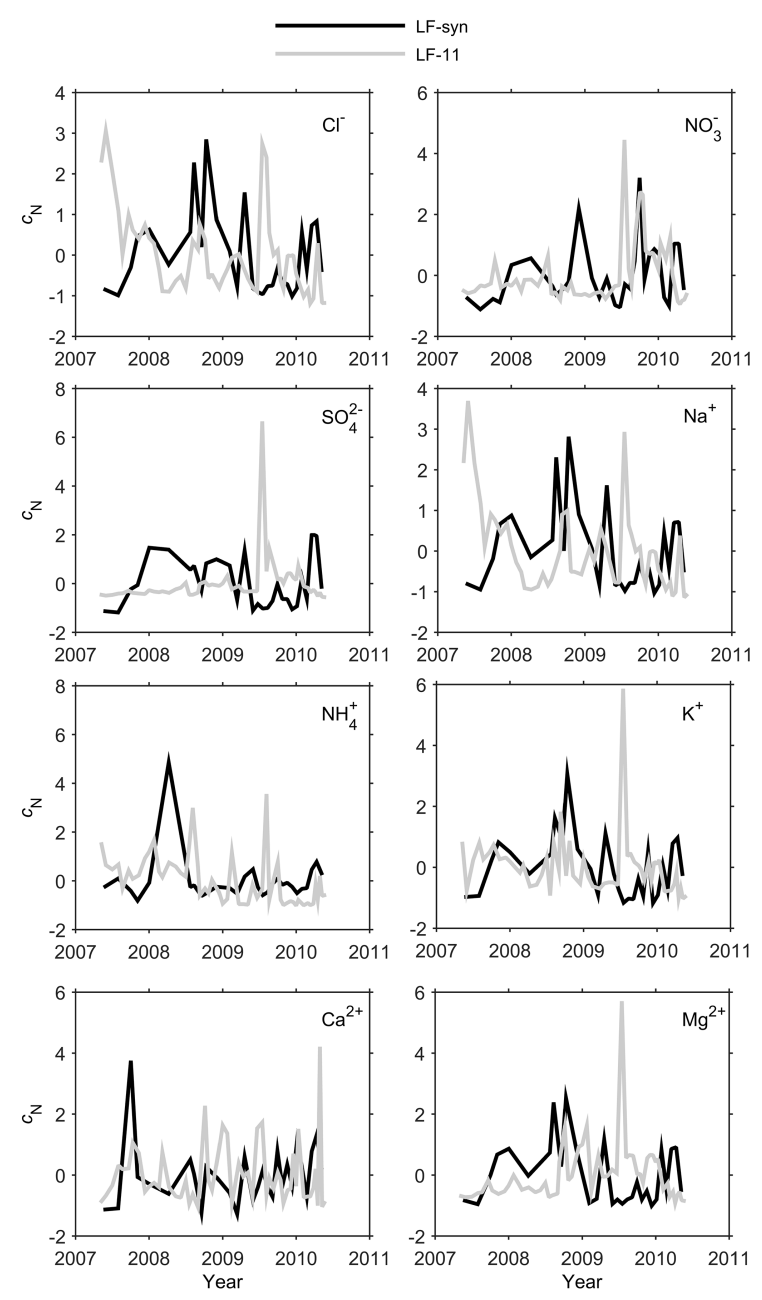

Figure 7. Comparison between a synthetic ice core (LF-syn, black) and the LF-11 ice core (grey). Ionic concentrations are normalized $\left(c_{\mathrm{N}}\right)$ to mean values according to the LF-syn ice core time scale.

melt event reported at Greenland on 12 July created a $2 \mathrm{~cm}$ ice crust at the surface of the snowpack at Summit, which is evidenced in the density profile in Fig. 10 (dashed line). Therefore, there is no evidence of intense melt at this site that could have generated melt water that percolated further down the snowpack. Therefore, we applied our method by comparing the snow pit sampled in late July with the snow pit sampled in 1 July. Following exactly the same methodology applied to Lomonosovfonna (with the exception of using the depth scale instead of the time scale), the ion normalized concentrations in the snow pits were calculated and shown in Fig. 11. The ionic record is spiky, as expected for any record of this kind, especially if no melting and percolation occurs. We proceeded then to calculate the difference between the snow pit sampled in 27 July (analogous to the LF-11 core) and the snow pit sampled in 1 July (analogous to the LF-syn unperturbed core). We also filtered out high-frequency variations using a low-pass filter (half-year moving average), as
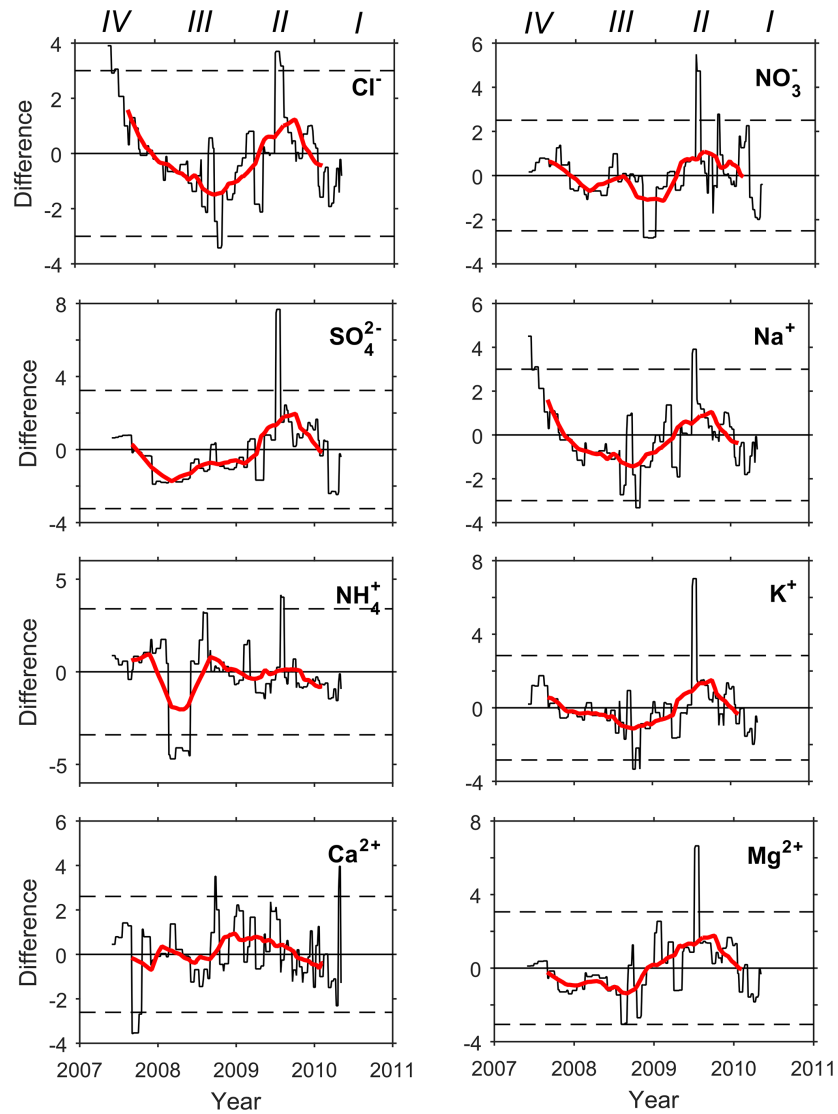

Figure 8. Difference between the normalized ionic concentrations $\left(c_{\mathrm{N}}\right)$ in the LF-11 and the LF-syn ice cores (black line). Twice the standard deviation (dashed black line) and zero values (horizontal line) are also shown. Deposition is a positive excursion and elution zones are negative excursions from the mean in each diagram. A low-pass filter (half-year moving average) is shown in red. Different periods of deposition and elution have been noted with Roman numerals.

we did with the Lomonosovfonna data. The results are shown in Fig. 12. As can be observed in Fig. 12, the filtered series do not deviate from the mean value of the concentrations; therefore, no percolation can be inferred from them, as can be expected to be the case for Summit during the period selected. We therefore consider that our method is applicable in Svalbard cores since it does not show false positives for the Greenland snow pits.

In order to estimate how the ionic relocation length during 2007-2010 is connected to meltwater percolation length and snowpack melting, we have estimated the melt percentage at Lomonosovfonna using two different methods, as shown in the following section.

\subsection{Meltwater production at Lomonosovfonna}

The produced meltwater obtained by using the PDD and snow-energy model approaches are shown in Fig. 13 for 


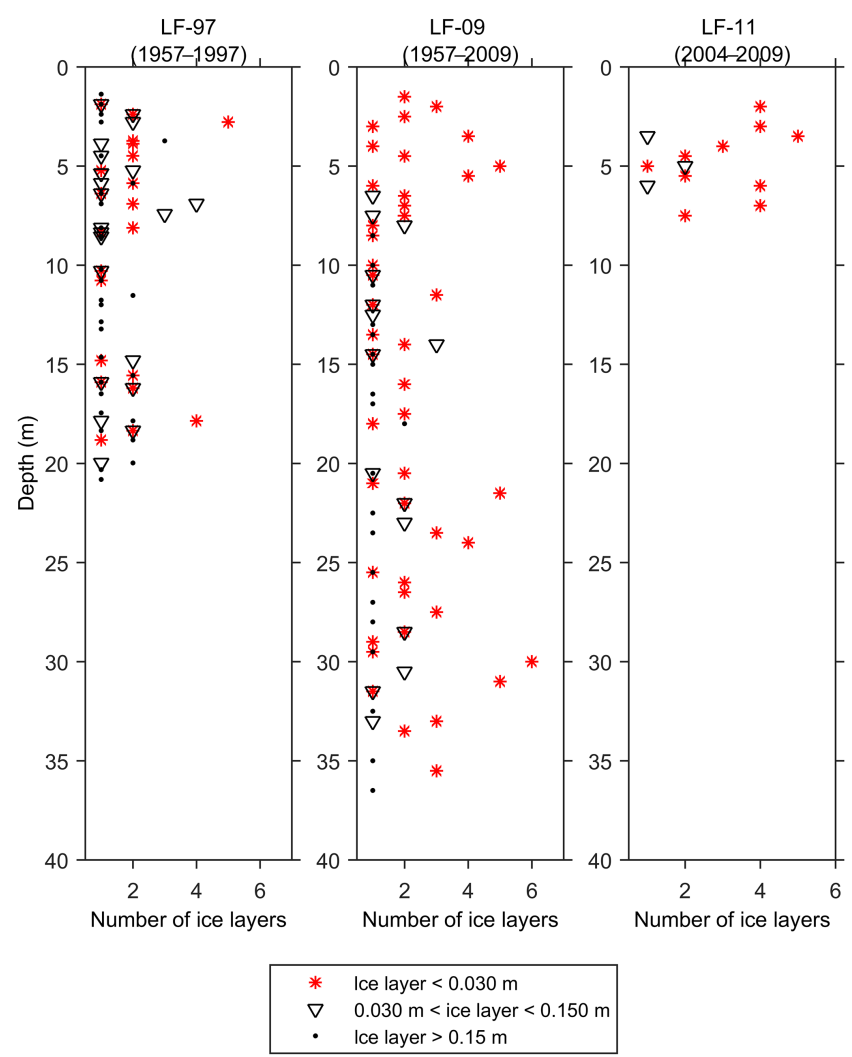

Figure 9. Number of ice layers found at different depths in the: LF97 (left), LF-09 (centre) and LF-11 (right) ice cores. The ice layers were divided in three classes according to their thickness: thin layers $(*)$, medium-thick layers $(\nabla)$ and thick layers $(\bullet)$.

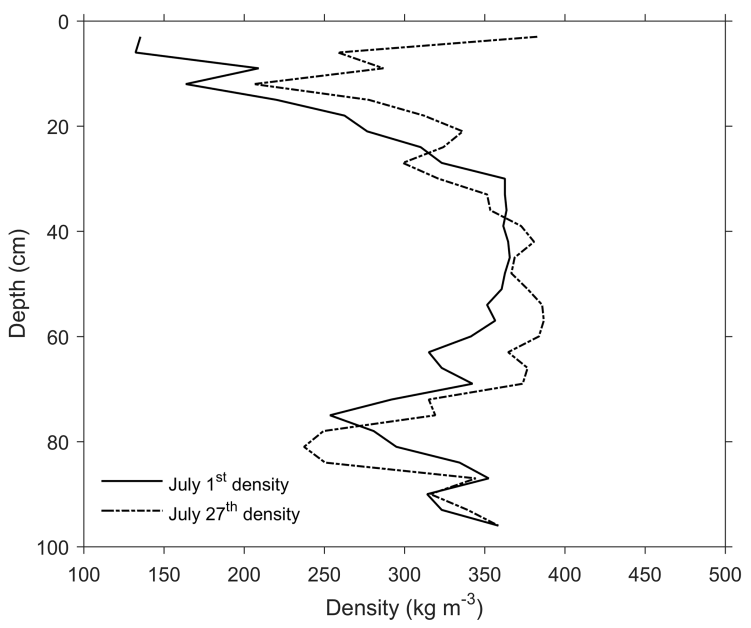

Figure 10. Density profiles in the snow pits sampled at Summit in 1 and 27 July 2012. The depth scale of the snow pit sample in 27 July was adjusted to find a reasonable match with the density profile of the snow pit sampled in 1 July.

the period 1979-2012 (calculated using PDD and instrumental temperatures), and 1989-2010 (using the snow-
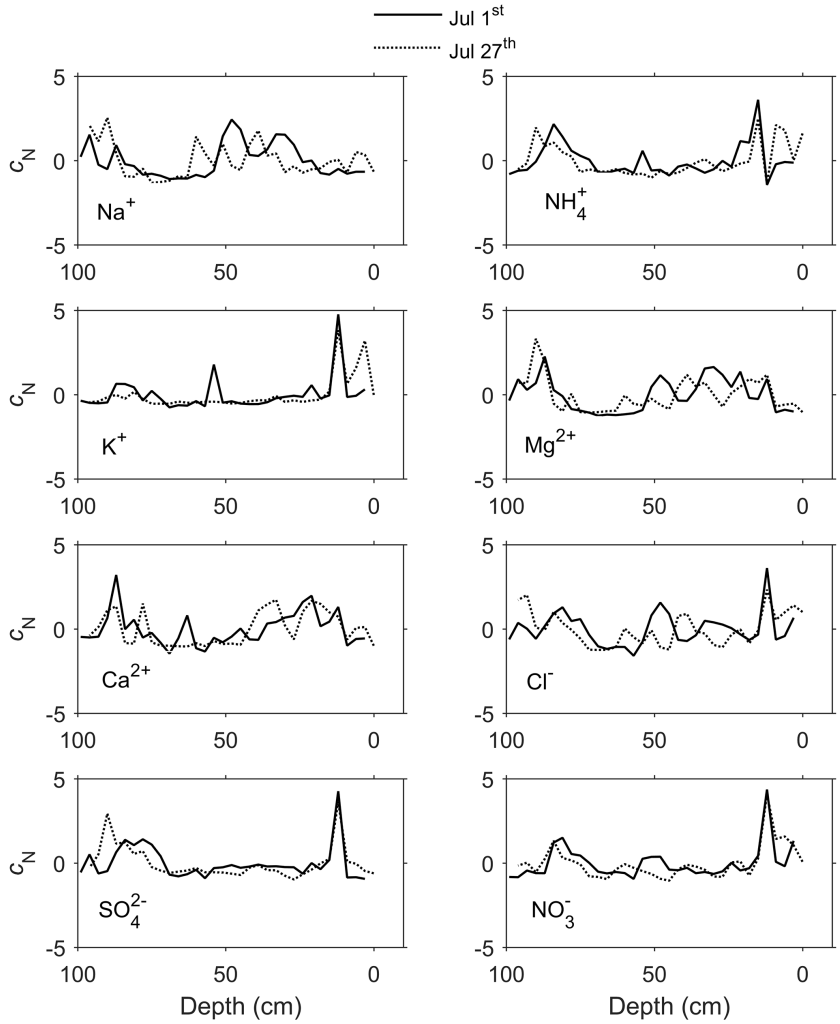

Figure 11. Comparison between the snow pit sampled in 1 July 2012 and the snow pit sampled in 27 July 2012. Ionic concentrations are normalized $\left(c_{\mathrm{N}}\right)$.

energy model). The production of meltwater at the summit of Lomonosovfonna has increased at a rate of $+0.0011 \mathrm{~m} \mathrm{yr}^{-1}$ w.e toward the last decades (corresponding to the linear trend of meltwater production calculated with the PDD and instrumental temperatures approach, Fig. 13). The average melting between 1989 and 2010 was calculated as $0.17 \mathrm{~m}$ w.e. when using the PDD and instrumental temperature approach. When considering the period between 2007 and 2010 (Fig. 14), the melting shows alternating warm and cold years (2007/2009, and 2008/2010, respectively), with meltwater average values of 0.19 and $0.27 \mathrm{~m}$ w.e. when using the instrumental temperatures, and the coupled snow-energy model, respectively. Alternatively, meltwater production was also calculated by using modelled temperatures obtained with the Polar WRF model at the summit of Lomonosovfonna and a DDF of $3.0 \mathrm{~mm}$ water ${ }^{\circ} \mathrm{Cday}^{-1}$. Average meltwater production levels of 0.07 and $0.05 \mathrm{~m}$ w.e. were obtained for the periods 1989-2010 and 2007-2010, respectively, when using the Polar WRF modelled temperatures. The meltwater production obtained by the Polar WRF approach gives values that are significantly lower than the meltwater obtained by using both the PDD and snow-energy model approaches, which is a consequence of the less number of PDDs per year estimated at the summit of Lomonosov- 

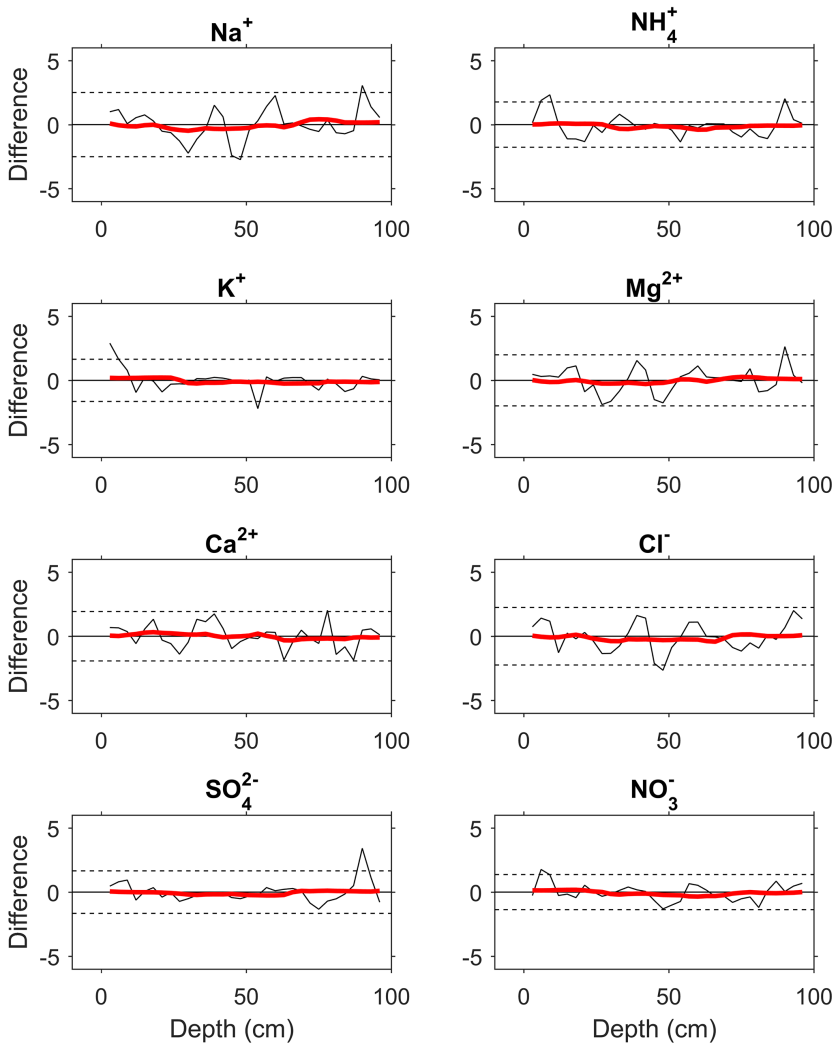

Figure 12. Difference between the normalized ionic concentrations $\left(c_{\mathrm{N}}\right)$ in the snow pit sampled in 27 and 1 July 2012. Twice the standard deviation and zero values are also shown. Deposition is a positive excursion and elution zones are negative excursions from the mean in each diagram.

fonna when using the Polar WRF model (i.e. 18 PDDs per year between 1989 and 2010) explained by the fact that the Polar WRF model produces lower surface temperatures compared to the lapse-rate-based temperatures at this site. Therefore, the meltwater calculated by using Polar WRF modelled temperatures were not considered in this study.

In order to estimate the impact of melting on the snowpack ionic content at the summit of Lomonosovfonna, the percentages of the annual snow accumulation that melts (Table 5) were calculated using the results in Figs. 13 and 14 and the annual accumulation rate between 2007 and 2010 at Lomonosovfonna obtained from the LF-09 and LF-11 cores. The melt percentage (MP) obtained by using the instrumental temperatures (48\% for the period 2007-2010) was on the order of previously reported values of $47 \%$ of melt during the warmest years and $28 \%$ during the coldest, during the period 1976-1995 (Pohjola et al., 2002). The relatively high MP values obtained in this study for the period 2007-2010 can be explained by the increase in temperatures at the site with a consequent steady increase of the number of PDD at the summit of Lomonosovfonna at a rate of 0.4 day $\mathrm{yr}^{-1}$ for the period 1979-2012 in which instrumental temperatures exist

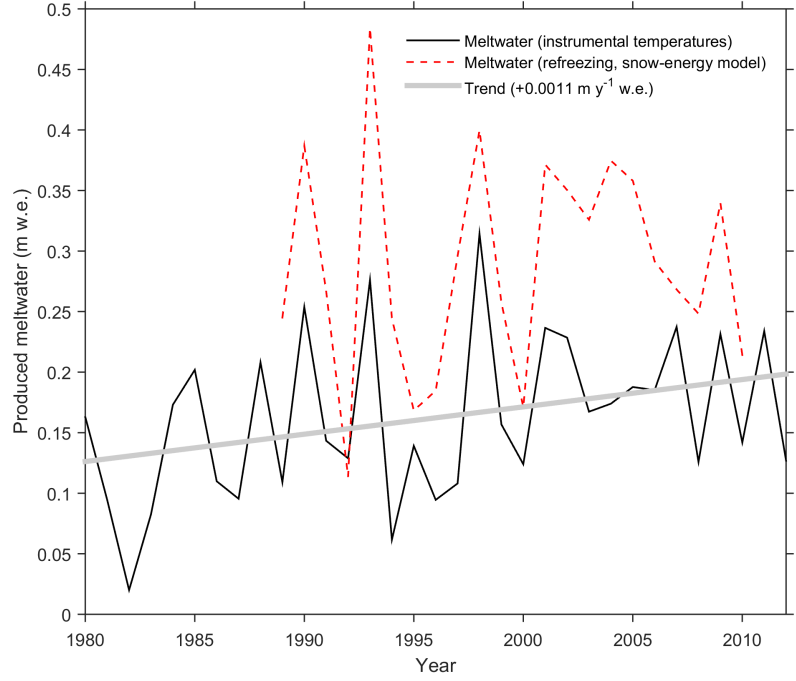

Figure 13. Produced meltwater calculated at Lomonosovfonna using the PDD (black) and snow-energy model (dashed red) approaches. The linear trend of meltwater calculated with the PDD approach and instrumental temperatures is also shown over the 19792012 period (grey).

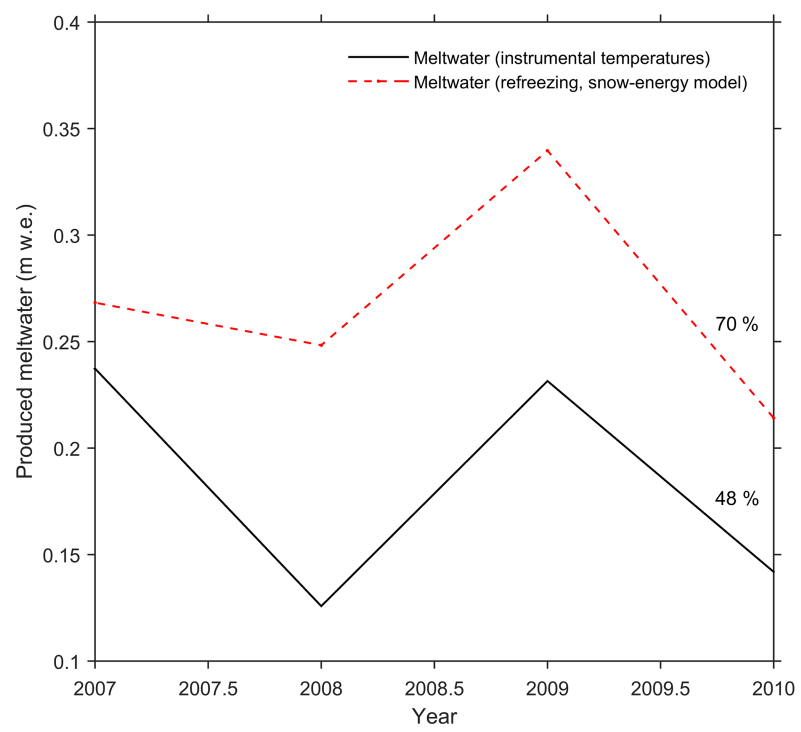

Figure 14. Meltwater calculated at Lomonosovfonna during the period 2007-2010 using the different approaches: PDD and instrumental temperatures (black); and the snow-energy model (dashed red). The percentages above each line represent the average melt percentage (MP) during the studied period, estimated by the different approaches.

in all the three stations used, Sveagruva, Ny-Ålesund and Longyearbyen airport; the MPs calculated using the PDD approach over the period 1979-2010 show a steady increase of $1 \% \mathrm{yr}^{-1}$ in line with the trend in decreasing the annual snow accumulation in $-0.01 \mathrm{~m} \mathrm{yr}^{-1}$ w.e. during the same period (accumulation data from the LF-09 ice core). 
Table 5. Percentages of melted annual snow accumulation (MP) calculated with the PDD approach (Pohjola et al., 2002; Nuth et al., 2012) using instrumental temperatures, and the snow-energy model (van Pelt et al., 2012).

\begin{tabular}{lrr}
\hline \multicolumn{3}{c}{ MP $(\%)$} \\
\hline Year & Instrumental temperatures & Snow-energy model \\
\hline 2010 & 34 & 52 \\
2009 & 55 & 81 \\
2008 & 34 & 68 \\
2007 & 69 & 78 \\
\hline Average & 48 & 70 \\
\hline
\end{tabular}

However, the calculated MPs using the PDD approach and the snow-energy do not agree with the results obtained by the synthetic core approach which suggest that melting during the 2007-2010 period has not been high (i.e $<50 \%$ ), which is also supported by the stratigraphy observed in the LF-09 and LF-11 cores (Fig. 9).

Due to the dissimilar results of MP obtained using the PDD and snow-energy model approaches (Table 5), we compared the density profiles of the shallow ice cores used in this study (LF-08, LF-09 and LF-11) with the total layer density values obtained using a simple firn-densification model (Reeh et al., 2005). The ice core density profiles were binned in annual averages in order to be comparable with the output of the firn-densification model. As described by Reeh et al. (2005), the model requires both annual average temperatures and snow accumulation at the study site as input, which were set as $-18.3^{\circ} \mathrm{C}$ and $0.39 \mathrm{~m}$ w.e., according to instrumental temperatures from Sveagruva, Svalbard Airport and Ny-Ålesund (the lapse rate employed to calculate the temperatures at the Lomonosovfonna summit was $-0.0044{ }^{\circ} \mathrm{C} \mathrm{m}^{-1}$ ), and average accumulation rates obtained from the LF-09 and LF-11 ice cores, respectively, for the period between 2007 and 2010. The firn-densification model also requires the surface snow density, which was set as $350 \mathrm{~kg} \mathrm{~m}^{-3}$, and a defined spatial resolution, set as $0.5 \mathrm{~m}$. The firn-densification model considers the percentage of melting as one of the input variables, showing output density values versus depth. Output densities of $900 \mathrm{~kg} \mathrm{~m}^{-3}$ are expected when the percentage of melt reaches $100 \%$. Four different melt scenarios where considered: MP equal to (a) $20 \%$, (b) $30 \%$, (c) $45 \%$, and (d) $70 \%$. The results of the comparison between the real ice core density profiles and the output of the firn-densification model are shown in Fig. 15.

According to Fig. 15, the firn-densification model shows better agreement with the measured density profiles in the top $10 \mathrm{~m}$ when the MP was set between 20 and $30 \%$. This agrees with the physical melt index of the LF-09 ice core (22\%), calculated as the percentage of clear ice present in the ice core (considering the ice core length in $\mathrm{m}$ w.e.). However, the agreement between the firn-densification model and the den- sity profiles is poor for depths deeper than $10 \mathrm{~m}$ (Fig. $15 \mathrm{a}-\mathrm{b}$ ) considering this range or MP. Figure $15 \mathrm{c}-\mathrm{d}$, show the comparison between the firn-densification model and the density profiles using a MP of 45 and $70 \%$. The agreement between the model and the measurements is better through the whole depth profile when setting the MP to $45 \%$ (Fig. 15 c). This agrees with the physical melt index of the LF-97 ice core (50\%), calculated between 1957 and 1997; however, it is not consistent with the physical melt index of the LF-09 ice core $(25 \%)$, calculated for the same period.

Considering the results shown in Table 5 and the firndensification model output shown in Fig. 15 a-d, it is plausible to think that the MP at Lomonosovfonna is not straight forward to estimate either using a simple PDD or the snowenergy model approach. Moreover, the use of Polar WRF temperatures at Lomonosovfonna as input to obtain the MP at the site is ruled out since it predicts MP values considerably lower than the values suggested by the density profiles both measured and modelled (i.e. an average MP of $12 \%$ for the period 2007-2010 when Polar WRF modelled temperatures and a DDF of $3.0 \mathrm{~mm}$ water ${ }^{\circ} \mathrm{C}_{\text {day }}{ }^{-1}$ are used to calculate the meltwater production). It also needs to be considered that the firn-densification model assumes a constant melt index during the ice core time span. Therefore, the firndensification model does not include the variability in meltwater production at Lomonosovfonna through time, which is key to the understanding of ion relocation within the snowpack at long time scales; however, the MP estimated here are suitable to understand the ionic relocation and water percolation during the period 2007-2010.

Figure 16 shows a comparison between the LF-11 and the LF-syn ice core depth-time scale. It is clear from Fig. 16 that the depth differences between the ice cores (black and grey lines) can be related to a partial melting of the snowpack and refreezing of the meltwater taking place between the 2007-2011 period, as evidenced by the ionic relocation. An estimate of the decrease in depth of the LF-syn ice core by the effects of snowpack melting considering a $\mathrm{MP}=20,30,48$ and $70 \%$ during 2007-2010 as suggested by the firn-densification model, MPs obtained using the PDD approach (using instrumental temperatures) and the snowenergy model is shown in Fig. 16. It can be observed that a $\mathrm{MP}=20-30 \%$ results in a LF-syn ice core depth-time scale highly similar to the depth-time scale of the LF-11 ice core during the 2007-2010 period, confirming that the MP during that period is coherent with the results of the firndensification model but not with the PDD results shown in Table 5. This relatively low MP reinforces the hypothesis that during this period, ion relocation took place at shallow depths $(0.5-2 \mathrm{~m})$ and that the meltwater percolation depth was most probably in the same order, with refreezing of meltwater within the snowpack pore space or by forming thin ice layers (0.03-0.15 m) (Fig. 9). 

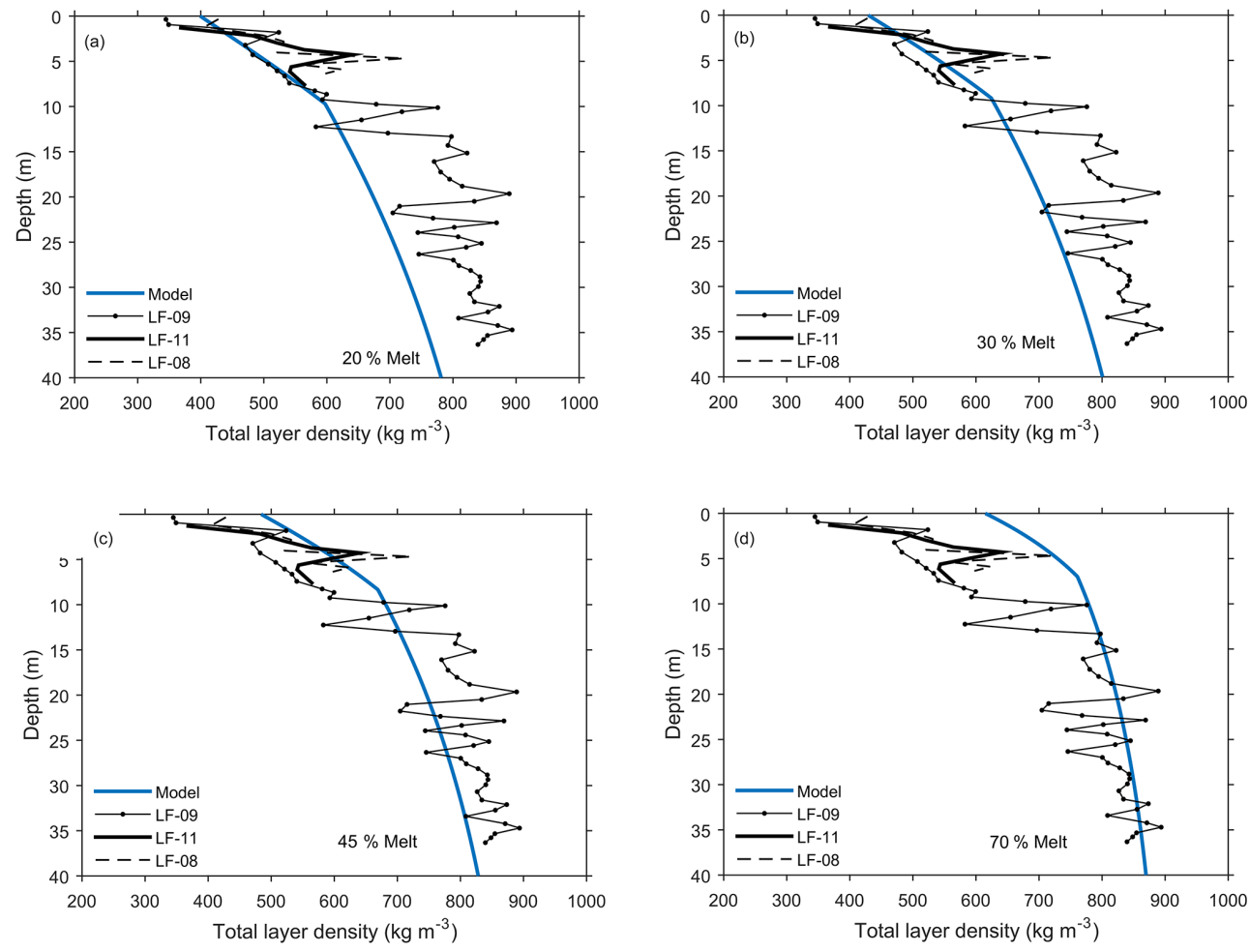

Figure 15. Comparison between the LF-08, LF-09 and LF-11 ice core density profiles (annual averages) and the output of the firndensification model (Reeh et al., 2005), considering: (a) $20 \%$ of melt, (b) $30 \%$ of melt, (c) $45 \%$ of melt, and (d) $70 \%$ of melt.

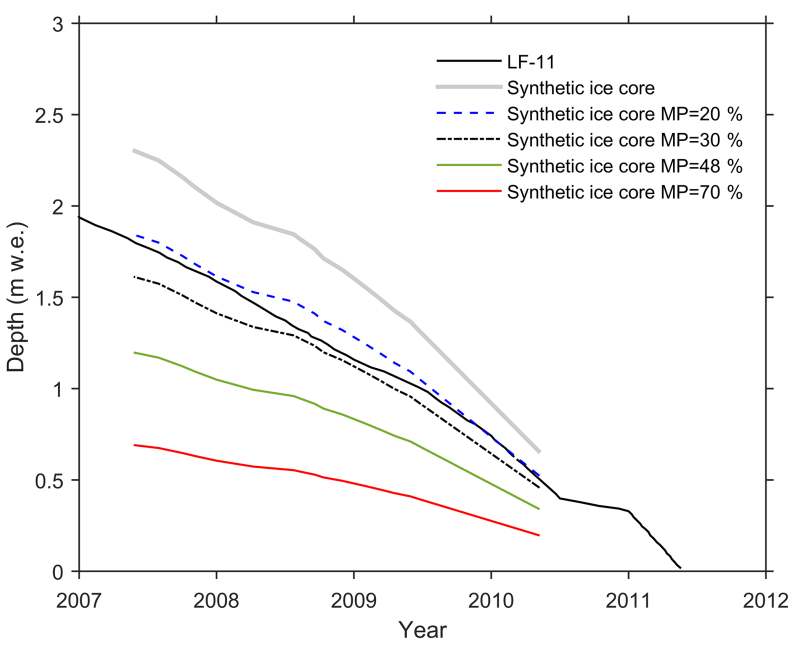

Figure 16. Depth-time scales for the LF-11 and LF-syn ice cores during 2007-2011 (black and grey lines, respectively). Blue dashed, black-dot-dashed, green and red lines represent the synthetic core depth-time scale considering a MP of 20, 30, 48 and $70 \%$, respectively.

\section{Conclusions}

By comparing different ice cores from Lomonosovfonna and using a synthetic ice core approach, we have been able to estimate the elution signal and relocation length of different ions measured at the study site, in order to assess the transfer function between the atmospheric ionic concentrations and the concentration in snow and ice.

Our results show good agreement between the ionic records of three different ice cores drilled during different years, using normalized concentrations and 5-year moving averages. Therefore, we reiterate that the different ice core records from Lomonosovfonna all share the same climatic and chemical features, despite the fact that cores have been retrieved in different years, were sampled at different resolutions, and were analysed at different laboratories. Our conclusion is that summer melting does not degrade the climatic signals.

By using the synthetic ice core approach, we could estimate a partial elution sequence for the summit of Lomonosovfonna, as $\mathrm{NO}_{3}^{-}>\mathrm{SO}_{4}^{2-}, \mathrm{Mg}^{2+}, \mathrm{Cl}^{-}, \mathrm{K}^{+}, \mathrm{Na}^{+}$, which agrees with previous reports. This elution sequence points towards the acidic ions as being the most mobile within the Lomonosovfonna snowpack. Considering the differences between the LF-11 and the LF-syn ice cores, we conclude that the relocation length of most the ions during the 2009-2010 period is on the order of $1 \mathrm{~m}$, therefore, the ions are eluted and re-deposited within the annual snow layer, considering present average accumulation rate at Lomonosovfonna (i.e. $<1 \mathrm{~m}$ of snow per year). Conse- 
quently, using 5-year moving averages of the ionic data allows having comparable records when different ice cores are used.

By using the PDD and the snow-energy model approaches to estimate the percentage of melt (MP) at Lomonosovfonna, we have estimated average annual MP in the range of 48 to $70 \%$ for the period between 2007 and 2010, in contrast to the lesser melting suggested by the LF-syn core for the same period. In order to constrain the MP, we have compared different density profiles obtained at the Lomonosovfonna drilling sites with a simple firn-densification model, obtaining a most probable average annual MP of $30 \%$ for the 2007-2010 period, which is consistent with the results of the synthetic ice core approach, and $45 \%$ of melt for the last 60 years. The lower melting percentages inferred for the 2007-2010 period compared with the whole period covered by the LF-09 core are most probably a result of a combination of relatively high snow accumulation rates and reduced PDD during the 20072010 period despite of the warmer conditions registered during the last decades.

Considering our findings, we conclude that despite of the warmer conditions and higher number of PDD registered at Lomonosovfonna during the last decades, the ionic signal affected by melting is retained within the same year of deposition for all major ions.

\section{Data availability}

Temperature data for Longyearbyen Airport, Sveagruva and Ny-Ålesund, in Svalbard is available at: http://eklima.met.no/, Greenland snow pit data of the Core Atmospheric Measurements at Summit is available at: https://arcticdata.io/catalog/\#view/urn:uuid: e9136a64-661f-470d-9b3a-72f31d54d066.

Acknowledgements. The authors want to thank the Lomonosovfonna 1997, 2008 and 2009 drilling teams and NPI field logistics for their support, C. Zdanowicz and G. Engström, Uppsala University, J. Moore, Arctic Centre, J. Zábori, Stockholm University, and S. Bejai, SLU for their comments and sharing of analytical lab facilities. This work was supported within the Marie Curie Initial Training Network NSINK ITN-2007.1.1, ENV., 215503 with complementary economic support by Ymer-80, the Arctic Fieldwork Grant by the Svalbard Science Forum, Uppsala Geographical Association, Sweden, and to the EU Regional Development Foundation, project 3.2.0801.12-0044.

Edited by: M. Schneebeli

\section{References}

Beaudon, E.: Glaciochemical evidence of spatial and temporal environmental variability across Svalbard, Arctic Centre Reports 58, Lapland University Press, Rovaniemi, ISBN-13: 978-952-484562-5, ISSN: 1235-0583, 2012.

Brimblecombe, P., Tranter, M., Abrahams, P. W., Blackwood, I., Davies, T. D., and Vincent, C. E.: Relocation and preferential elution of acidic solute through the snowpack of a small, remote, high-altitude Scottish catchment, Ann. Glaciol., 7, 141147, 1985.

Bøggild, C. E.: Preferential flow and melt water retention in cold snow packs in West-Greenland, Nord. Hydrol., 31, 287-300, 2000.

Claremar, B.: Relation between meso-scale climate and glacier/snow mass balance on Svalbard, Dept. Earth Sciences, Uppsala University, SVALI Technical report, available at: http://ncoe-svali.org/xpdf/svali_report_d2-3-11_fin.pdf, 2013.

Colbeck, S. C.: The layered character of snow covers, Rev. Geophys., 29, 81-96, 1991

Divine, D., Isaksson, E., Martma, T., Meijer, H. A. J., Moore, J., Pohjola, V., van de Wal, R. S. W., and Godtliebsen, F.: Thousand years of winter surface air temperature variations in Svalbard and northern Norway reconstructed from ice-core data, Polar Res., 30, 7379, doi:10.3402/polar.v30i0.7379, 2011.

Eichler, A., Schwikowski, M., and Gäggeler, H. W.: Meltwaterinduced relocation of chemical species in alpine firn, Tellus B, 53, 192-203, 2001

Førland, E. J., Benestad, R., Hanssen-Bauer, I., Haugen, J. E. and Skaugen, T. E.: Temperature and precipitation development at Svalbard 1900-2100, Adv. Meteorol., 2011, 893790 doi:10.1155/2011/893790, 2011.

Ginot, P., Schotterer, U., Stichler, W., Godoi, M. A., Francou, B., and Schwikowski, M.: Influence of the Tungurahua eruption on the ice core records of Chimborazo, Ecuador, The Cryosphere, 4, 561-568, doi:10.5194/tc-4-561-2010, 2010.

Goto-Azuma, K. and Koerner, R. M.: Ice core studies of anthropogenic sulfate and nitrate trends in the Arctic, J. Geophys. Res. 106, 4959-4969, 2001.

Goto-Azuma, K., Nakawo, M., Jiankang, H., Watanabe, O., and Azuma, N.: Melt-induced relocation of ions in glaciers and in a seosanal snowpack. Snow and Ice covers: Interactions with the Atmosphere and Ecosystems, Proceedings of Yokohama Symposia J2, July 1993, IAHS Publ. no. 223, 287-297, 1994.

Grinsted, A., Moore, J., Pohjola, V., Martma, T., and Isaksson, E. Svalbard summer melting, continentality, and sea ice extent from the Lomonosovfonna ice core, J. Geophys. Res., 111, D07110, doi:10.1029/2005JD006494, 2006.

Hastings, M. G., Steig, E. J., and Sigman, D. M.: Seasonal variations in $\mathrm{N}$ and $\mathrm{O}$ isotopes of nitrate in snow at Summit, Greenland: Implications for the study of nitrate in snow and ice cores, J. Geophys. Res., 109, D20306, doi:10.1029/2004JD004991, 2004.

Hastings, M. G., Sigman, D. M., and Steig, E. J.: Glacial/interglacial changes in the isotopes of nitrate from the Greenland Ice Sheet Project 2 (GISP2) ice core, Glob. Biochem. Cycles, 19, GB4024, doi:10.1029/2005GB002502, 2005.

Hastings, M. G., Jarvis, J. C., and Steig, E. J.: Anthropogenic impacts on nitrogen isotopes of ice-core nitrate, Science, 324, 1288 , doi:10.1126/science.1170510, 2009. 
Honrath, R. E., Peterson, M. C., Guo, S., Dibb, J. E., Shepson, P. B., and Campbell, B.: Evidence of NOx production within or upon Ice particles in the Greenland snowpack, Geophys. Res. Lett., 26, 695-698, 1999.

Iizuka, Y., Igarashi, M., Kamiyama, K., Motoyama, H., and Watanabe, O.: Ratios of $\mathrm{Mg}^{+2} / \mathrm{Na}^{+}$in snowpack and ice core at Austfonna ice cap, Svalbard, as an indicator of seasonal melting, J. Glaciol., 48, 452-460, 2002.

Isaksson, E., Pohjola, V., Jauhiainen, T., Moore, J., Pinglot, J. F., Vaikmäe, R., van de Wal, R. S. W., Hagen, J. O., Ivask, J., Karlöf, L., Martma, T., Meijer, H. A. J., Mulvaney, R., Thomassen, M., and van den Broeke, M.: A new ice-core record from Lomonosovfonna, Svalbard: viewing the 1920-97 data in relation to present climate and environmental conditions, J. Glaciol., 47, 335-345, 2001.

Kekonen, T., Moore, J. C., Mulvaney, R., Isaksson, E., Pohjola, V., and Van De Wal, R. S. W.: A 800 year record of nitrate from the Lomonosovfonna ice core, Svalbard, Ann. Glaciol., 35, 261-265, 2002.

Kekonen, T., Moore, J., Perämäki, P., Mulvaney, R., Isaksson, E., Pohjola, V., and van de Wal, R. S. W.: The 800 year long ion record from the Lomonosovfonna (Svalbard) ice core, J. Geophys. Res., 110, D07304, doi:10.1029/2004JD005223, 2005.

Laj, P., Palais, J. M., and Sigurdsson, H.: Changing sources of impurities to the Greenland Ice-sheet over the last 250 years, Atmos. Environ., 26, 2627-2640, 1992.

Moore, J. C. and Grinsted, A.: Ion fractionation and percolation in ice cores with seasonal melting, in: Physics of Ice Core Records II: Papers collected after the 2nd International Workshop on Physics of Ice Core Records, held in Sapporo, Japan, 2-6 February 2007, edited by: Hondoh, T., Vol. 68, 2009.

Moore, J. C., Grinsted, A., Kekonen, T., and Pohjola, V.: Separation of melting and environmental signals in an ice core with seasonal melt, Geophys. Res. Lett., 32, L10501, doi:10.1029/2005GL023039, 2005.

Moore, J. C., Beaudon, E., Kang, S., Divine, D., Isaksson, E., Pohjola, V. A., and van de Wal, R. S. W.: Statistical extraction of volcanic sulphate from nonpolar ice cores, J. Geophys. Res., 117, D03306, doi:10.1029/2011JD016592, 2012.

Nghiem, S. V., Hall, D. K., Mote, T. L., Tedesco, M., Albert, M. R., Keegan, K., Shuman, C. A., DiGirolamo, N. E., and Neumann, G.: The extreme melt across the Greenland ice sheet in 2012, Geophys. Res. Lett., 39, L20502, doi:10.1029/2012GL053611, 2012.

Nuth, C., Vikhamar, Schuler, T. V., Kohler, J., Altena, B., and Hagen, J. O.: Estimating the long-term claving flux of Kronebreen, Svalbard, from geodetic elevation changes and mass-balance modelling, J. Glaciol., 58, 119-133, 2012.

Pinglot, J. F., Pourchet, M., Lefauconnier, B., Hagen, J. O., Isaksson, E., Vaikmäe, R., and Kamiyama, K.: Accumulation in Svalbard glaciers deduced from ice cores with nuclear tests and Chernobyl reference layers, Polar Res., 18, 315-321, 1999.

Pohjola, V. A., Moore, J. C., Isaksson, E., Jauhiainen, T., van de Wal, R. S. W., Martma, T., Meijer, H. A. J., and Vaikmäe, R.: Effect of periodic melting on geochemical and isotopic signals in an ice core from Lomonosovfonna, Svalbard, J. Geophys. Res., 107, 4036, 10.1029/2000JD000149, 2002.
Reeh, N., Fisher, D. A., Koerner, R. M., and Clausen, H. B.: An empirical firn-densification model comprising ice lenses. Ann. Glaciol., 42, 101-106, 2005.

Rempel, A. W., Wettlaufer, J. S., Waddington, E. D.: Anomalous diffusion of multiple impurity species: Predicted implications for the ice core climate records, J. Geophys. Res., 107, ECV 3-1ECV 3-12, doi:10.1029/2002JB001857, 2002.

Röthlisberger, R., Hutterli, M. A., Wolff, E. W., Mulvaney, R., Fischer, H., Bigler, M., Goto-Azuma, K., Hansson, M., Ruth, U., Siggaard, M.-L., Steffensen, J. P.: Nitrate in Greenland and Antarctic Ice cores: a detailed description of post-depositional processes, Ann. Glaciol., 35, 209-216, 2002.

Schöndorf, T. and Herrmann, R.: Transport and chemodynamics of organic micropollutants and ions during snowmelt, Nord. Hydrol., 18, 259-278, 1987.

Skamarock, W. C., Klemp, J. B., Dudhia, J., Gill, D. O., Barker, D. M., Duda, M. G., Huang, X.-Y., Wang, W., and Powers, J. G.: A description of the advanced research WRF version 3. NCAR/TN-475+STR, NCAR Technical Notes, Mesoscale and Microscale Meteorology Division, National Center for Atmospheric Research, Boulder, Colorado, USA, 2008.

Summit snow pit data: NSF Arctic Data Center, available at: https://arcticdata.io/catalog/\#view/urn:uuid: e9136a64-661f-470d-9b3a-72f31d54d066, last access: 5 May 2016.

Temperature data: Norwegian Meteorological Institute MET Norway, available at: http://eklima.met.no/, last access: 31 July 2015.

van Pelt, W. J. J., Oerlemans, J., Reijmer, C. H., Pohjola, V. A., Pettersson, R., and van Angelen, J. H.: Simulating melt, runoff and refreezing on Nordenskiöldbreen, Svalbard, using a coupled snow and energy balance model, The Cryosphere, 6, 641-659, doi:10.5194/tc-6-641-2012, 2012.

van Pelt, W. J. J., Pettersson, R., Pohjola, V. A., Marchenko, S., Claremar, B., and Oerlemans, J.: Inverse estimation of snow accumulation along a radar transect on Nordenskiöldbreen, Svalbard, J. Geophys. Res.-Earth, 119, 816-835, doi:10.1002/2013JF003040, 2014.

Vega, C. P., Björkman, M. P., Pohjola, V. A., Isaksson, E., Pettersson, R., Martma, T., Marca, A. D., and Kaiser, J.: Nitrate stable isotopes and major ions in snow and ice samples from four Svalbard sites, Polar Res., 34, 23246, doi:10.3402/polar.v34.23246, 2015a.

Vega, C. P., Pohjola, V. A., Samyn, D., Pettersson, R., Isaksson, E., Björkman, M. P., Martma, T., Marca, A. D., and Kaiser, J.: First Ice Core Records of Nitrate Stable Isotopes from Lomonosovfonna, Svalbard. J. Geophys. Res.-Atmos., 120, doi:10.1002/2013JD020930, 2015b.

Wendl, I. A., Eichler, A., Isaksson, E., Martma, T., and Schwikowski, M.: 800-year ice-core record of nitrogen deposition in Svalbard linked to ocean productivity and biogenic emissions, Atmos. Chem. Phys., 15, 7287-7300, doi:10.5194/acp-157287-2015, 2015.

Wilson, A. B., Bromwich, D. H., and Hines, K. M.: Evaluation of Polar WRF forecasts on the Arctic System Reanalysis domain: Surface and upper air analysis, J. Geophys. Res., 116, D11112, doi:10.1029/2010JD015013, 2011. 